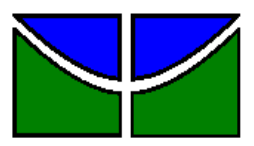

Universidade de Brasília

Faculdade de Planaltina - FUP

Programa de Pós-Graduação em Gestão Pública - PPGP

ALINE IZABEL TOLENTINO DE ANDRADE

O PERFIL DO ALUNO REINTEGRADO NOS CURSOS DE GRADUAÇÃO DA UNIVERSIDADE DE BRASÍLIA: UMA ANÁLISE POR MEIO DA REGRESSÃO LOGÍSTICA

Brasília - DF 
O PERFIL DO ALUNO REINTEGRADO NOS CURSOS DE GRADUAÇÃO DA UNIVERSIDADE DE BRASÍLIA: UMA ANÁLISE POR MEIO DA REGRESSÃO LOGÍSTICA

Dissertação apresentada ao Programa de PósGraduação em Gestão Pública, como requisito parcial para obtenção do grau de Mestre em Gestão Pública.

Orientador: Prof. Dr. Luiz Honorato da Silva Júnior

Brasília-DF 
Ficha catalográfica elaborada automaticamente,

com os dados fornecidos pelo(a) autor(a)

Tolentino de Andrade, Aline Izabel

TAN553 Tolentino de Andrade, Aline Izabel
O PERPIL DO ALUNO REINTEGRADO NOS CURSOS DE

P GRADUAÇ̄̃O DA UNIVERSIDADE DE BRASFLIA: TMA ANÁLISB

POR MEIO DA REGRESSĂO LOGfSTICA / Aline Izabel

Tolentino de Andrade; orientador Luiz Honorato Da

Silva Junior. -- Brasilia, 2016.

85 p.

Dismertaç̄o (Meatrado - Meatrado Profinaional em

Gentäo Pública) -- Univeraidade de Branilia, 2016.

1. Rnaino Superior. 2. Bvaño. 3. Perfil do

aluno. 4. Reintegração. 5. Regreasão Logiatica. I. Da Silva Junior, Luiz Honorato, orient. II. Titulo. 


\title{
O PERFIL DO ALUNO REINTEGRADO NOS CURSOS DE GRADUAÇÃO DA UNIVERSIDADE DE BRASÍLIA: UMA ANÁLISE POR MEIO DA REGRESSÃO LOGÍSTICA
}

\begin{abstract}
Dissertação apresentada ao Programa de Pós-Graduação em Gestão Pública da Faculdade de Planaltina, Mestrado Profissional em Gestão Pública, como requisito parcial para obtenção do grau de Mestre em Gestão Pública, julgada pela Comissão Examinadora, abaixo identificada.
\end{abstract}

\section{COMPOSIÇÃO DA BANCA EXAMINADORA:}

Prof. Dr. Luiz Honorato da Silva Júnior

Professor-Orientador

Prof. Dr. Alexandre Nascimento

Professor-Examinador Interno
Prof. Dr. José Angelo Belloni

Professor-Examinador Externo

Brasília, 27 de julho de 2016. 
DEDICO Este Trabalho

A Deus, que me ensina a vencer os obstáculos da minha vida e me dá forças e inspiração todos dias, em especial para concluir esta pesquisa.

Ao meu marido Wolney, que acreditou em mim e esteve sempre comigo na busca da realização deste trabalho, sem ele eu não teria conseguido.

A minha mãe, que apesar de não estar mais comigo sempre foi um exemplo de vida e de admiração para mim. Ela, com todo o seu amor e dedicação, me ensinou que o estudo é base fundamental para vencer na vida e que por isso nunca poderia desistir de lutar.

Aos meus familiares e amigos, que acreditaram na minha capacidade de vencer e me ajudaram com suas presenças fraternas. 


\section{AGRADECIMENTOS}

O primeiro agradecimento é ao senhor Deus, todo poderoso, que me deu sabedoria, perseverança e forças para concluir este trabalho.

Agradeço ao meu marido Wolney, pela sua compreensão e companheiro que mesmo nos dias mais difíceis me ensinou a ter fé para não desistir. Sem ele eu não teria conseguido.

A minha mãe, (em memória), que sempre me ensinou que o estudo é a base fundamental para vencer na vida e que por isso nunca poderia desistir de lutar.

A minha irmã, familiares e amigos, que me ajudaram com suas presenças fraternas. Em especial ao meu tio Newton, que é como um pai para mim e sempre acreditou na minha capacidade de vencer

Ao Wagner, que me ajudou na compreensão do método de estatística e sem ele e o meu marido eu não teria conseguido chegar aos resultados desta pesquisa.

Ao professor Luiz Honorato, pela disponibilidade e críticas necessárias ao trabalho durante esse período de convivência.

A todos os professores do Programa de Pós-graduação em Gestão Pública da Universidade de Brasília, por terem participado da minha formação. Aos professores Alexandre Nascimento e José Angelo Belloni, por terem aceitado participar da minha banca, pelas contribuições ao meu trabalho e pela paciência.

À Professora Nara Pimentel, que apesar dos poucos momentos juntas me incentivou, e me apoio durante todo o período que precisei, e que, juntamente com o Prof. Mauro Rabelo, me orientou e me acolheu em momentos difíceis no ambiente de trabalho.

A todos os meus colegas do curso do Mestrado, pela oportunidade de convivência, amizade e aprendizado, assim como pelo apoio e por juntos conseguirmos realizar um intercâmbio para Portugal, concretizando muitos sonhos.

Aos meus colegas de trabalho da Secretaria de Pós-Graduação da FS, que me incentivaram e me ajudaram a não desistir. Aos meus outros colegas da UnB Danilo por me auxiliou em todas as etapas do início do mestrado e Angélica, Juliana e Nicole que me deu apoio em alguns momentos difíceis.

À Secretaria do programa, que auxiliou em todos os momentos. A todos que colaboraram para a minha formação, direta ou indiretamente, e que não foram aqui mencionados, meus sinceros agradecimentos. 
Eu quero saber como Deus criou este mundo. Não estou interessado neste ou naquele fenômeno, no espectro deste ou daquele elemento. Eu quero conhecer os pensamentos dele, o resto são detalhes. 


\section{RESUMO}

O objetivo deste trabalho é avaliar quais são as características observáveis atribuídas aos estudantes relacionadas à chance de conseguir retornar aos cursos de graduação e, uma vez o discente reintegrado à universidade, à probabilidade de concluir o seu curso de graduação. Para isso, foi utilizado para a análise o método de regressão logit binário. Os dados compreendem 18.268 alunos evadidos da Universidade de Brasília no período entre os anos de 2000 e 2014. Os resultados obtidos mostram o impacto das variáveis observáveis como faculdades, idade, sexo, regionais federativas de nascimento, o tipo de curso que estava fazendo, o tempo de permanência na instituição, as formas de ingresso e os motivos do desligamento. Espera-se contribuir para que, com essas informações, tanto a Universidade de Brasília como outras instituições de ensino, públicas ou privadas, possam tomar medidas mais eficientes para reduzir o número de evasão nos cursos de graduação, melhorar o aproveitamento acadêmico dos estudantes, reduzir os gastos públicos, além de aprimorar outros fatores como a qualidade do ensino superior.

Palavras Chaves: Ensino Superior. Evasão. Reintegração. Regressão Logística. Perfil do aluno. 


\begin{abstract}
The objective of this study is to evaluate what are the observable characteristics attributed to students related to the chance of returning to undergraduate courses and, once reinstated to the university, to the probability of completing their undergraduate degree. For this, the binary logit regression method was used as the data analysis methodology. The database, which was run in the SPSS computer program, included the years from 2000 to 2014 , comprising 18.268 observations. The results show the impact of observable variables, such as colleges, age, gender, State of birth, type of course, duration of permanence in the institution, registration forms and the dismissal reasons. It is expected to contribute, with this information, so that both the University of Brasilia and other educational institutions, public or private, can take more efficient measures to reduce the number of evasion in undergraduate courses, improve the academic achievement of students, reduce public money expenditure, and improve other factors such as the quality of higher education.
\end{abstract}

Key Words: Higher Education. Evasion. Reinstated Student. Binary Logit Regression. Student Profile. 


\section{LISTA DE ILUSTRAÇÕES}

Figura 1- Fluxograma das formas de ingresso e saída da UnB ................................... 22

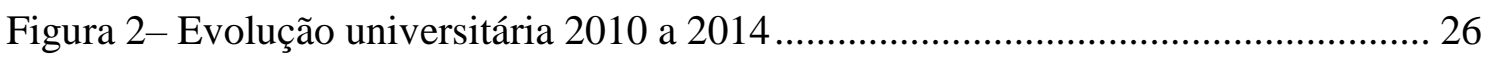

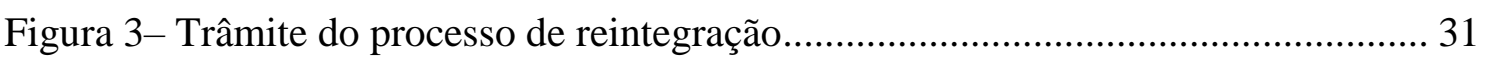

Figura 4- Número de discentes desligados da graduação por Instituto ou Faculdade da

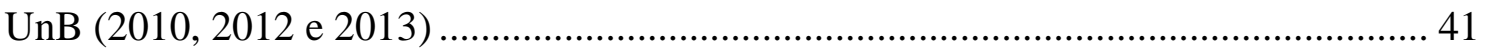

\section{LISTA DE TABELAS}

Tabela 1 - Estatísticas Descritivas das Variáveis que compõem os Reintegrados (R) .. 47 Tabela 2 - Estatísticas Descritivas das Variáveis que compõem a subpopulação de

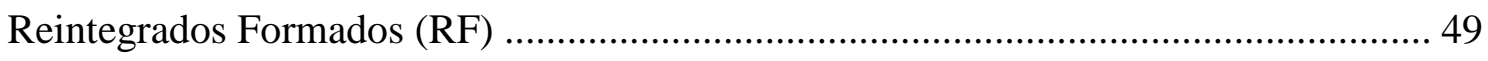

Tabela 3 - Resultados das regressões logit para os dois modelos propostos ................. 54

\section{LISTA DE QUADROS}

Quadro 1 - Relação das Faculdades e cursos da UnB .................................................. 27

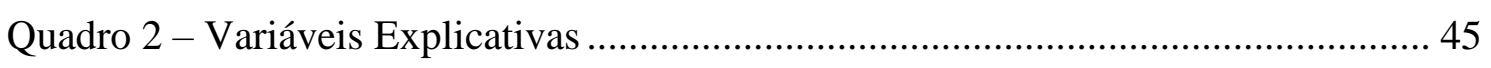




\section{LISTA DE ABREVIATURAS E SIGLAS}

$\boldsymbol{C A O}$ - Comissão de Acompanhamento e Orientação

$\boldsymbol{C E G}$ - Câmara de Ensino de Graduação

CEPE - Conselho de Ensino, Pesquisa e Extensão

CET - Centro de Excelência em Turismo

CPD - Centro de Informática da UnB

DEG - Decanato de Ensino de Graduação

DF - Distrito Federal

ENEM - Exame Nacional do Ensino Médio

FAC - Faculdade de Comunicação

FACE - Faculdade de Economia, Administração e Contabilidade

$\boldsymbol{F A U}$ - Faculdade de Arquitetura e Urbanismo

$\boldsymbol{F A V}$ - Faculdade de Agronomia e Medicina Veterinária

FCE - Faculdade UnB Ceilândia

FCI - Faculdade de Ciências da Informação

FD - Faculdade de Direito

$\boldsymbol{F E}$ - Faculdade de Educação

FEF - Faculdade de Educação Física

FGA - Faculdade UnB Gama

FIES - Fundo de Financiamento ao Estudante do Ensino Superior

FM - Faculdade de Medicina

FS - Faculdade de Ciências da Saúde

FT - Faculdade de Tecnologia

FUB - Fundação Universidade de Brasília

FUP - Faculdade UnB Planaltina

IB - Instituto de Ciências Biológicas

ICS - Instituto de Ciências Sociais

IdA - Instituto de Artes

$\boldsymbol{I E}$ - Instituto de Ciências Exatas

IES - Instituição de Ensino Superior

IF - Instituto de Física

IG - Instituto de Geociências 
IH - Instituto de Ciências Humanas

IL - Instituto de Letras

IN - Instrução Normativa

INEP - Instituto Nacional de Pesquisas Educacionais

IP - Instituto de Psicologia

IPOL - Instituto de Ciências Políticas

IQ - Instituto de Química

IREL - Instituto de Relações Internacionais

LEAP - Aprendendo a Estabelecer Prioridades Acadêmicas (sigla em inglês)

MEC - Ministério da Educação

PAS - Programa de Avaliação Seriada

PDI - Plano de Desenvolvimento Institucional

ProUni - Programa Universidade Para Todos

$\boldsymbol{R}$ - Reintegrados

Reuni - Reestruturação das Universidades

$\boldsymbol{R} \boldsymbol{F}$ - Reintegrados e formados

RICs - Regiões de Influência

SAA - Secretaria de Administração Acadêmica

SESU - Secretaria de Educação Superior

SIGRA - Sistema de Informações Acadêmicas

SOU - Serviço de Orientação Acadêmica

$\boldsymbol{U A B}$ - Universidade Aberta do Brasil

UnB - Universidade de Brasília

UDF - Centro Universitário do Distrito Federal

USP - Universidade de São Paulo 


\section{SUMÁRIO}

1. INTRODUÇÃ

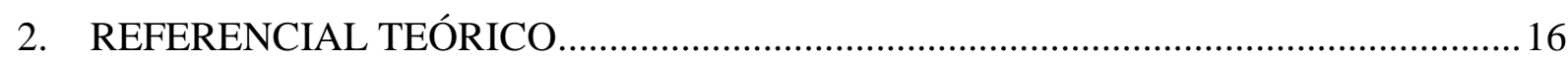

1.1 A Evasão Escolar .................................................................................. 16

1.2 A dinâmica do processo da escolha do curso, evasão, reintegração e

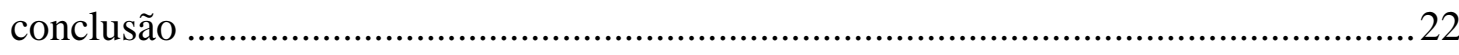

1.3 A Universidade de Brasília ............................................................................... 24

1.4 O Processo de Reintegração...............................................................................29

1.4.1 Instruções Normativas sobre o desligamento e a reintegração dos alunos

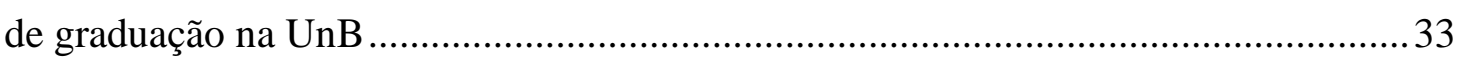

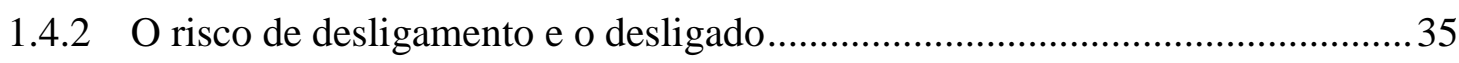

1.4.3 A reintegração e a solicitação de reintegração..................................................... 37

1.4.4 Dados de Evasão dos últimos anos na UnB .....................................................40

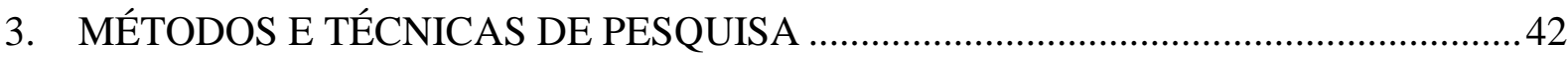

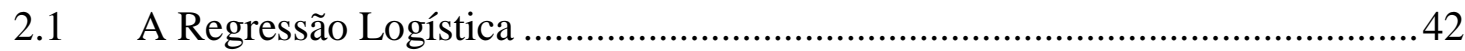

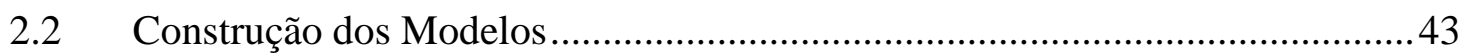

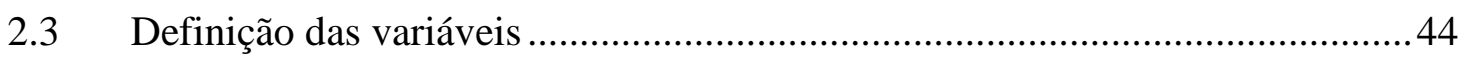

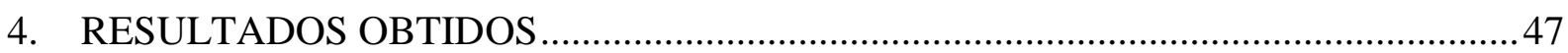

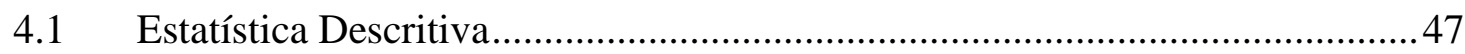

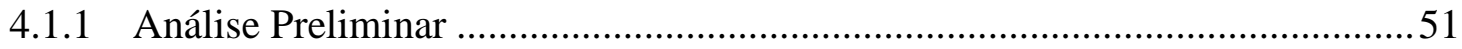

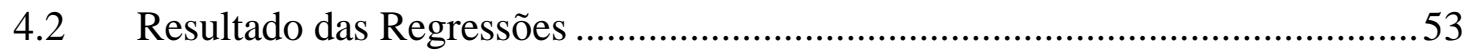

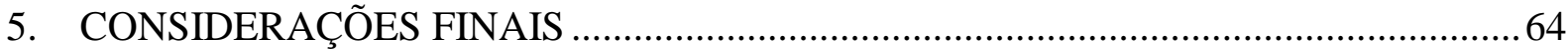

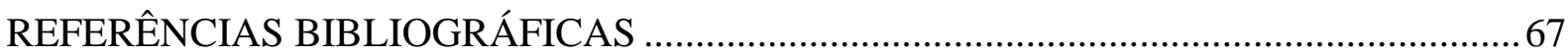

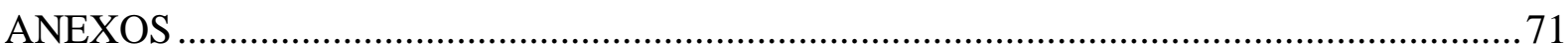




\section{INTRODUÇÃO}

Com o grande crescimento das universidades brasileiras, nos últimos anos, houve um maior número de oferta de vagas no ensino superior público, criação de novos cursos, o aumento no quadro dos servidores e professores, entre outros fatores. Com essa expansão, muitos passaram a ter acesso ao ensino superior. Essa realidade exige que as instituições adotem cada vez mais medidas para atender e acompanhar todos seus alunos, pois não basta ter acesso, é preciso permanecer nas instituições em seus cursos escolhidos, e cabe às universidades buscar combater a evasão.

O processo de retornar para a instituição de ensino é um dos mecanismos que ajudam no melhor acompanhamento psicopedagógico adequado aos estudantes e a reduzir as altas taxas de evasão. A reintegração, apesar de ser um processo diferente, está relacionada à evasão, já que o aluno que se reintegra foi antes evadido da instituição de ensino.

Com o mundo cada vez mais globalizado e competitivo como o de hoje, as pessoas precisam estar cada vez mais preocupadas em obter um maior nível de escolaridade. Alguns fatores inerentes às pessoas podem contribuir para que não seja possível concluir um curso de graduação e ter que se inserir rapidamente no mercado de trabalho. Porém, mesmo com os adventos da vida, aqueles alunos que têm o interesse em investir em seu capital humano buscam a reintegração para obter melhores oportunidades de trabalho e garantir um bom futuro.

O objetivo deste trabalho é avaliar quais são as características observáveis atribuídas aos estudantes relacionadas à chance de conseguir retornar aos cursos de graduação e, uma vez o discente reintegrado à universidade, à probabilidade de concluir o seu curso de graduação. Com isso, pergunta-se, qual é o perfil do aluno, da UnB, que mais retorna aos cursos de graduação?

Algumas variáveis foram utilizadas para melhor entender o perfil do aluno reintegrado e o perfil do aluno reintegrado formado nos cursos de graduação. As principais delas são: gênero, influências regionais (dentro ou fora do seu estado de convivência), idade, curso escolhido, campus, forma de ingresso na instituição, motivo do desligamento, entre outras. 
Assim, esta pesquisa tem por objetivo geral identificar o perfil dos alunos da Universidade de Brasília que são reintegrados e que, em seguida, se formaram nos seus cursos de graduação, utilizando-se para isso um modelo de regressão logística.

Além desse objetivo geral, espera-se, a partir de regressões logísticas, identificar as principais variáveis observáveis que ajudam a explicar o perfil do reintegrado típico; traçar o perfil do indivíduo típico que foi reintegrado e que concluiu o curso de graduação na universidade; e, ainda, fornecer subsídios à Universidade no que tange a implementação de futuras políticas públicas no sentido de mitigar o problema da evasão nos cursos de graduação.

Espera-se que este estudo possa contribuir com a discussão do tema para a comunidade cientifica e acadêmica, uma vez que um estudo com a abordagem apresentada pode servir como insumo para subsidiar melhorias na tomada de decisão quanto às regras e normas institucionais relacionadas à evasão e ao retorno do aluno à Universidade de Brasília e na construção de políticas públicas, alertando para a necessidade de mudanças na instituição. 


\section{REFERENCIAL TEÓRICO}

Será apresentado brevemente o estado da arte em relação ao tema investigado. Inicialmente, será feita uma breve discussão sobre o processo de evasão escolar, escolha do curso, reintegração e conclusão. Instruções normativas sobre desligamento e a reintegração dos alunos da UnB, a solicitação de reintegração e dados dos últimos anos de evasão na UnB.

\subsection{A Evasão Escolar}

É sabida a importância da educação para o desenvolvimento de uma nação. A educação é a grande propulsora do desenvolvimento. Os retornos econômicos da educação são significativos. Tendo tal percepção há uma busca incessante para o aumento da escolaridade no Brasil. Se a oferta de vagas não acompanha, pode-se ter um enorme déficit educacional. De olho nisso, forças governamentais (via universidades públicas) e de mercado (universidades privadas) têm feito esforços no sentido de atender tal demanda.

Mais recentemente, no início dos anos 2000, houve uma significativa ampliação da oferta de vagas no ensino superior público, permitindo que candidatos que outrora dificilmente teriam acesso ao ensino superior público, quando o número de vagas era mais restrito, tivessem maiores chances.

Alguns estudiosos do tema como Severino (2009 p.256) afirmam que a ampliação de vagas deu nova conformidade ao sistema, trazendo novas características, como, por exemplo, o número de evasão. O autor apresenta dados que confirmam que as taxas de evasão continuaram altas em 2007. "Esta taxa foi de 41,9\%, sendo 27,4\% no ensino público federal, $36,2 \%$ no ensino público estadual, 37,6\% no ensino público municipal, 44,6\% no ensino privado".

O conceito de evasão a ser considerado neste estudo foi definido pela Comissão Especial de Estudos sobre a Evasão, criada em 1995 pela Secretaria de Educação Superior (SESU), do Ministério da Educação (MEC). Essa comissão definiu a evasão como sendo "a saída definitiva do aluno de seu curso de origem, sem concluí-lo" (BRASIL, 1997, p. 19). 
Nesse contexto de expansão do ensino superior e de aumento do acesso às universidades, é importante compreender o fenômeno da evasão, uma vez que ele está essencialmente relacionado à reintegração. Cabe esclarecer que a reintegração é um processo que busca justamente reduzir os índices de evasão, na medida em que almeja manter o aluno na universidade.

Ao analisar as causas da evasão em sua pesquisa, Lobo (2012) levou em conta o crescente número de matrículas e as razões do reconhecimento tardio desse problema nas Instituições do Ensino Superior (IES). A autora destaca a importância da discussão sobre as melhorias e medidas a serem tomadas para o controle e diminuição da evasão e frisa que é necessário estudar os dados de cada instituição, devido às peculiaridades de cada uma, e após isso aprofundar as principais ações pertinentes que deverão ser tomadas em cada caso. Ela destaca que as principais causas frequentes da evasão são:

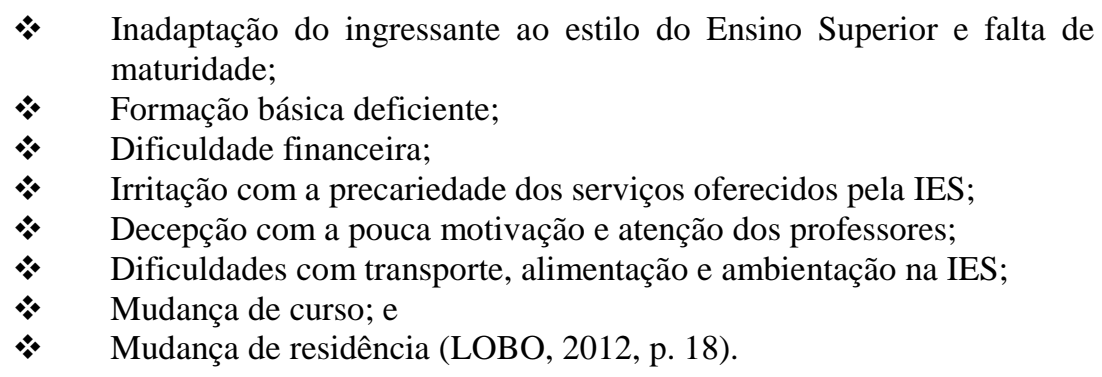

Outra possível causa da evasão é que o aluno se desmotiva ao se deparar com um curso não desejado em um determinado estabelecimento. Para o aluno, "o custo benefício do "sacrifício" para obter um diploma superior na carreira escolhida não vale mais a pena”. (SILVA FILHO et al., 2007, p. 643).

Em pesquisa realizada no campus de Cuiabá, na Universidade Federal do Mato Grosso, identificou-se também que o aluno evadido é aquele que necessita trabalhar para se sustentar e com isso acaba abandonando o ambiente universitário. O estudo pondera ainda que a evasão vai além do processo dependente do aluno, sendo então um fenômeno institucional causado pela falta de política de permanência do aluno na instituição (VELOSO e ALMEIDA, 2001).

Além das causas da evasão, é importante considerar as consequências desse fenômeno. Silva Filho et al. (2007) abordam o fato de que quando os estudantes começam e não terminam os cursos de graduação são considerados desperdícios acadêmicos, sociais e econômicos. Em órgãos do Governo, é um dinheiro público investido pelo Estado na educação de alunos, mas que não tem o devido retorno. Nas 
instituições privadas, é a perda da receita. Nos dois casos, quando existe a evasão, tornase desnecessária a contratação de mais professores e funcionários, assim como a compra de equipamentos e o investimento em espaço físico, o que não é bom para a instituição.

Esse prejuízo para a universidade também foi objeto de consideração do estudo de caso realizado por Veloso e Almeida (2001), na Universidade Federal do Mato Grosso, em que foi aplicado um questionário com perguntas fechadas e abertas aos coordenadores de 14 cursos de graduação do campus de Cuiabá. A pesquisa acrescentou dados à compreensão do fenômeno da evasão em uma concepção institucional. Para os autores, a universidade não deve ser medida pelo índice de diplomação, o desempenho a ser avaliado vai além de títulos expedidos, há também a formação cultural e introdução na sociedade, a produção e sistematização do conhecimento.

É importante destacar que o problema da evasão não está restrito ao Brasil outros países precisam enfrentar o mesmo problema. A pesquisa desenvolvida pelos autores Silva Filho et al. (2007), que teve como metodologia a coleta e organização dos dados sobre índices de evasão anual, média e por instituição de algumas regiões, acrescentou alguns dados com os índices de evasão internacionais para fazer uma comparação com os índices brasileiros. Os dados fornecidos pelo Instituto Nacional de Pesquisas Educacionais (INEP), referentes aos anos de 2000 a 2005, revelaram que esses índices nacionais e internacionais não diferem muito, de modo que não foi possível afirmar que a evasão no ensino superior brasileiro é pior ou melhor do que a média dos índices internacionais, que variam de país a país.

Conforme os resultados levantados na pesquisa feita por Silva Filho et al. (2007), no período analisado, as taxas de evasão foram maiores nas instituições de ensino privado e, entre as universidades públicas, as instituições municipais apresentaram os maiores índices. Dos estudos realizados no exterior, a taxa de evasão no mundo foi três vezes maior no primeiro ano de graduação, comparado aos demais anos de estudo. Uma das principais justificativas dadas pelas instituições, tanto públicas como privadas, é o fator financeiro, ou seja, o aluno não tem condições financeiras para continuar o curso.

Reynolds (2013), da Universidade de Kent State nos Estados Unidos, cuja pesquisa trata sobre os fatores que influenciam na decisão de solicitar a reintegração, afirma que existe uma crescente quantidade de pesquisas sobre alunos em risco de desligamento ou em fase probatória, mas poucos estudos que focam na população de 
alunos reintegrados. Relata também que não há estudos dentro do universo acadêmico que tratam especificamente das experiências e das necessidades dos alunos reintegrados.

Ressalta-se que a falta de preparo acadêmico deixa o estudante vulnerável por não ter as habilidades necessárias para lidar com o rigor acadêmico do ensino de nível superior. O insucesso acadêmico do aluno pode então resultar em diversas ações por parte da universidade, incluindo o risco de desligamento, suspensão ou o próprio desligamento (REYNOLDS, 2013).

$\mathrm{Na}$ Universidade Estadual de Kent há um programa de intervenção acadêmica denominado Aprendendo a Estabelecer Prioridades Acadêmicas (LEAP, na sigla em inglês), que se destina aos alunos que estão em processo de reintegração. Esse programa serve um duplo propósito de oferecer os meios para que o aluno melhore suas chances de sucesso acadêmico e evite prejuízos para a instituição de ensino ao retornar à situação de risco, mas também de fornecer à própria universidade mais um instrumento para auxiliar na tomada de decisão sobre reintegrar o aluno ou não.

Destaca-se que na Universidade de Brasília (UnB) não há um programa de intervenção acadêmica durante $o$ processo de reintegração. Existe apenas $o$ acompanhamento do discente em situação de condição, ou seja, em risco de ser desligado, ou após a sua reintegração, por meio de planos de acompanhamento acadêmico feito pelo professor orientador ou pela orientação pedagógica feita pelo Serviço de Orientação Acadêmica (SOU) do Decanato de Ensino de Graduação (DEG).

A pesquisa de Reynolds (2013) identificou alguns fatores, com base em revisões acadêmicas, que podem influenciar no sucesso do aluno em situação de risco:

- Identidade e desenvolvimento da carreira;

* Desempenho nas disciplinas;

* Índice de rendimento acadêmico;

* Tempo decorrido desde o desligamento;

* Componentes e grau de intervenção de programas de assistência ao aluno;

* Características pessoais;

* Cursos sobre habilidades para os estudos;

* Aconselhamento acadêmico individual ou em grupo;

* Sessões de estudos obrigatórias;

* Entre outras. 
O método utilizado na pesquisa de Reynolds (2013) foi baseado em entrevistas de estudos de casos naturalistas, o qual resultou em uma análise construtivista sobre a percepção dos alunos em processo de reintegração quanto a suas necessidades e experiências ao participarem do programa de intervenção.

Trabalho como o de Osborne (2013), que trata sobre o mesmo assunto, cita que, embora o desligamento de alunos afete os índices de retenção de uma instituição, as questões relacionadas ao processo de desligamento e aos estudantes impactados por ele têm recebido pouca atenção. Há poucas estatísticas norte-americanas disponíveis sobre essa população. A Universidade Estadual da Califórnia relata que aproximadamente 650 alunos são desligados por ano.

São poucas as pesquisas sobre o número de estudantes que são reintegrados e subsequentemente alcançam o sucesso acadêmico. Muitas universidades não registram os índices de graduação ou reintegração dessa população. Essa ausência de pesquisa torna desafiador para os administradores das universidades desenvolver orientações para a reintegração e implementar programas de assistência a essa população, a fïm de melhor assegurar que aqueles que são reintegrados tenham uma maior probabilidade de sucesso na graduação (OSBORNE, 2013).

O propósito da pesquisa de Osborne (2013), que consiste em revisão de literatura e entrevistas, foi fornecer subsídios para os administradores da universidade, por meio de uma abordagem qualitativa, para identificar as experiências dos alunos reintegrados que persistiram na graduação e as variáveis que eles acreditam terem influenciado seu sucesso.

Para Osborne (2013), os administradores precisam de políticas de reintegração baseadas em informações mais precisas, para determinar a probabilidade de sucesso acadêmico de alunos reintegrados. Esse sucesso é medido pelo quanto o aluno avança no curso. Toda essa visão e conhecimento sobre a reintegração pode ser usada pelos administradores para melhor servir os estudantes atuais e futuros, por meio de um processo de reintegração mais eficiente, incluindo políticas e serviços de apoio.

Alguns dos resultados encontrados nas entrevistas realizadas por Osborne (2013) mostram que a maioria dos alunos que obtiveram um melhor sucesso acadêmico após a reintegração foram aqueles que optaram pela mudança de curso. Esses alunos relataram que as dificuldades acadêmicas enfrentadas estavam relacionadas à falta de metas 
acadêmicas ou de carreira, ou ao fato de considerarem que os cursos anteriores não eram adequados a suas habilidades. Outro ponto a ser destacado dos resultados é que para alguns dos entrevistados o fato de estarem afastados dos estudos e depois retornar contribuiu para o sucesso acadêmico, pois esse período de afastamento teria ajudado a encontrar um foco e a resolverem questões pessoais.

[...] os Coordenadores de Curso indicam como um dos fatores que contribuem para a evasão - o fato do aluno buscar [sic] o curso de baixa demanda na expectativa de uma vez ter ingressado, buscar o curso de "sua verdadeira opção" através de Transferência Interna. Como nem sempre isto é viabilizado, principalmente pela não oferta de vaga para este tipo de ingresso, o aluno busca um novo concurso vestibular (VELOSO e ALMEIDA 2001, p. 138).

Salienta-se que algumas das características abordadas nas pesquisas realizadas nas Universidades da Califórnia e Kent nos Estados Unidos mostram algumas semelhanças com a realidade do Brasil. Semelhanças como alunos que não tinham o devido preparo acadêmico para lidar com o rigor que exige uma universidade, a escolha de um curso que não corresponde às habilidades ou expectativas de carreira, a falta de foco e a necessidade de resolverem questões pessoais. Infelizmente, são pouquíssimos estudos, pesquisas e estatísticas dos fatores que influenciam no alcance do sucesso acadêmico dos alunos que são desligados e decidem solicitar a reintegração. Cabe destacar que a falta de pesquisas mais detalhadas colabora para a falta de instrumentos para que as universidades tenham uma melhor tomada de decisão do retorno ou não desses alunos, para que não haja uma política de reintegração e até mesmo a devida implementação de programas de assistência aos alunos desligados.

[...] embora a evasão seja um fenômeno de causas variadas, a intervenção da universidade através de alterações de currículos, adequação de metodologias de ensino e de processos de avaliação, além da introdução de mecanismos de acompanhamento de estudantes, pode reduzir sensivelmente suas dimensões, sobretudo naqueles cursos em que as taxas são mais elevadas (BRAGA, PEIXOTO e BOGUTCHI, 2003, p. 186).

Ressalta-se que um dos mecanismos para combater a evasão, além de inclusão social e assistência estudantil, com auxílios moradias, transporte e alimentação, entre outras ações, é o processo de reintegração. Esse processo consiste em oferecer para todos aqueles alunos que não cumpriram com as normas internas a possibilidade do retorno à instituição. 
É importante frisar que a evasão e a reintegração são processos distintos com características próprias, mas que estão relacionados entre si, uma vez que o aluno que se reintegra foi evadido da instituição de ensino. Esse incentivo à reintegração tem a devida efetividade quando há uma boa estrutura institucional e o acompanhamento psicopedagógico adequado aos estudantes. Assim fica claro a compreensão dos aspectos relativos à evasão e como eles se relacionam com o processo de reintegração.

1.2 A dinâmica do processo da escolha do curso, evasão, reintegração e conclusão

Para entender um pouco melhor sobre os custos e os benefícios envolvidos na decisão de um aluno retornar ou não ao curso de graduação, criou-se um fluxograma para melhor visualização dos inputs (entradas) e outputs (saídas) de todo o ciclo que está relacionado no investimento do aluno em seu próprio capital humano. A Figura abaixo apresenta um fluxograma explicativo das formas de ingresso e saída do aluno de graduação da UnB.

Figura 1- Fluxograma das formas de ingresso e saída da UnB

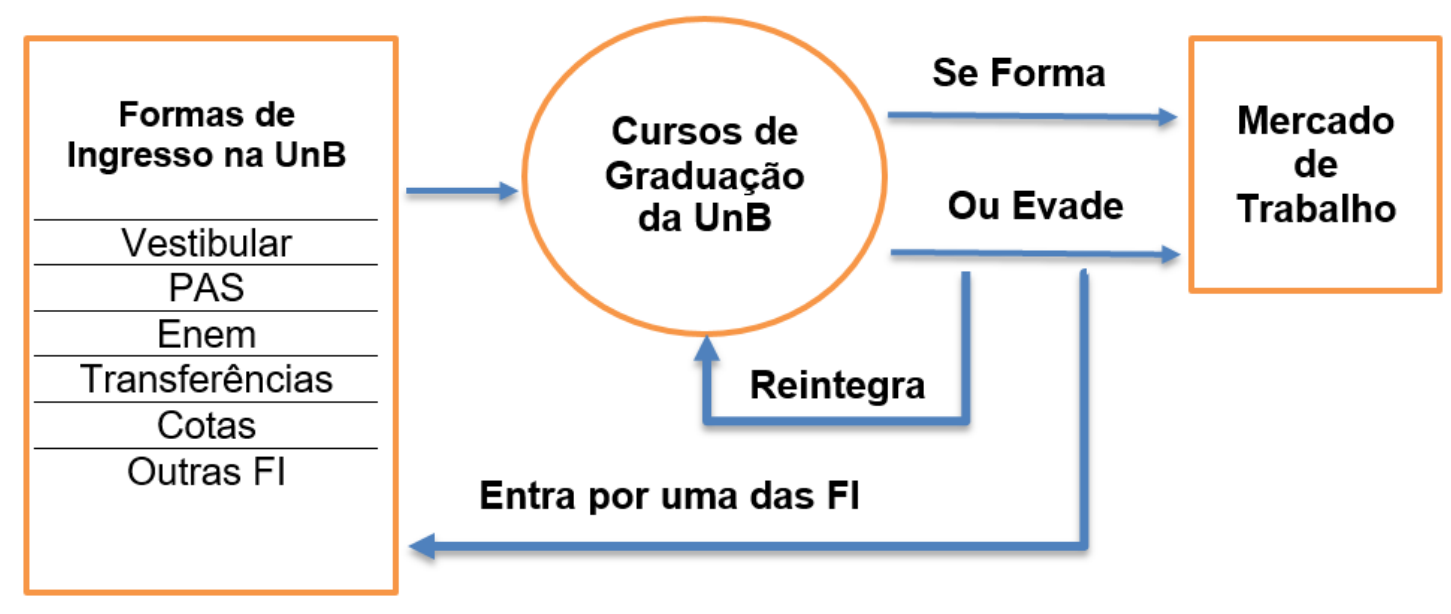

Fonte: Elaborado pela autora

Conforme se verifica na Figura 1, a dinâmica de ingresso se dá, principalmente por vestibular, Programa de Avaliação Seriada (PAS), Exame Nacional do Ensino Médio (ENEM), transferências, políticas de cotas, acordos culturais, entre outras formas de ingresso.

Durante o seu processo de formação, o estudante pode chegar à etapa final de um curso de graduação e se formar, ou sair precocemente da instituição na forma de 
evasão. Em alguns casos de evasão, o discente tenta sua inserção no mercado de trabalho.

Para outras situações de evasão o aluno tenta retornar para o curso por meio da reintegração. Podem ser apontadas como umas das principais causas de evasão a falta de identidade com o curso que está fazendo, não conseguir rendimento acadêmico necessário ou por perda de rendimento.

O estudante que não encontrou identidade com o curso que está fazendo é facilmente verificado, por exemplo, em cursos de medicina, que mesmo sendo um dos cursos de maior dificuldade de acesso, encontra alunos que evadem voluntariamente.

Há o caso daqueles discentes que não conseguem rendimento necessário para concluir. Esse é o caso de boa parte dos cursos ligados à área de exatas como matemática, estatística e engenharias. Observe que no percurso os alunos tendem a encontrar sérias dificuldades em continuar por precisarem superar disciplinas de alta complexidade como é o caso das disciplinas de cálculo- obrigatória do currículo do curso.

Razões por problemas pessoais de força maior que o levam a uma momentânea perda de rendimento e o consequente desligamento, são casos que parece ser mais frequente na solicitação de reintegração.

De toda forma, a conclusão é sempre vista como algo extremamente importante pelo estudante e seus entes queridos. São percebidos como potencializadores de oportunidades no mercado de trabalho e garantia de um futuro melhor.

Conforme Silva Junior (2009), a formação é um dos fatores que levaram alguns países a obter uma rápida recuperação econômica, após a Segunda Guerra Mundial, concluindo então que a rápida recuperação se deu ao fato da população desses países serem saudáveis e investirem em sua própria educação. As pessoas são mais produtivas ao terem educação.

A Comissão Especial de Estudos sobre a Evasão enfatiza que apesar de o estudante ter interesse por uma determinada área, muitas vezes opta por mudar de curso devido às grandes barreiras do mercado de trabalho. No País assolado pelas crises econômicas, em que a maioria desses estudantes vem de classes desfavorecidas, as questões relativas à remuneração tornam-se fundamentais na escolha da profissão (BRASIL, 1997). 
Do ponto de vista estritamente financeiro, se um agente racional tivesse que decidir sobre o quanto estudar, ele deveria estimar quanto o aumento de sua escolaridade traria de elevação em sua remuneração e se ele poderia esperar pelo início de seu ingresso no mercado de trabalho para compensar os custos que teve (ou que seus pais tiveram) que, inicialmente, suportar. (SILVA JUNIOR, 2009, p. 47).

Apesar de no Brasil ser possível concluir todo o ciclo da educação básica no Sistema Público, até mesmo o ensino superior, os altos índices de evasão escolar são o reflexo de que muitas pessoas se deparam com os vários outros custos diretos e indiretos que impossibilitam o investimento e a continuidade na educação, tais como as suas restrições orçamentárias (SILVA JUNIOR e SAMPAIO, 2013).

É preciso destacar que a maioria das pessoas que entram no mercado de trabalho necessita estar em constante atualização. Os alunos desejam ter uma formação complementar e moderna sobre determinado curso, vinculada às demandas da globalização, da sociedade. As metodologias utilizadas de forma repetitiva, a atuação de professores poucos comprometidos ou a falta de corpo docente em alguns cursos contribuem para agravar a evasão (BRASIL, 1997).

Cabe destacar, a esse respeito, que, assim como a opção de duplo curso ou mudança de curso, a reintegração pode estar relacionada aos custos financeiros ou de oportunidade envolvidos na decisão de investir na sua formação, pela expectativa de um emprego melhor no futuro, ou de buscar uma inserção no mercado de trabalho sem concluir o ensino superior.

Portanto, quando os alunos de graduação evadem para uma possível inserção no mercado de trabalho mais cedo, estão reduzindo seu custo sem capital humano, na melhoria de suas habilidades e técnicas para uma melhor mão de obra qualificada.

\subsection{A Universidade de Brasília}

O Distrito Federal tinha quase dois anos de existência quando a Fundação Universidade de Brasília (FUB) foi criada, por meio da Lei $\mathrm{n}^{\circ}$. 3.998, de 15 de dezembro de 1961. O campus foi construído pelos idealizadores Darcy Ribeiro, antropólogo, que definiu as bases da instituição, e o educador Anísio Teixeira, que desenvolveu o projeto pedagógico. 
Universidade de Brasília (UnB). Instituída por meio da Lei no 3.998, de 15 de dezembro de 1961, a UnB surge não apenas como a mais moderna universidade do país naquele período, mas como um divisor de águas na história das instituições universitárias, quer por suas finalidades, quer por sua organização institucional, como o foram a USP e a UDF nos anos 30 (FÁVERO, 2006, p.29).

A Universidade foi fundada com a ideia de redescobrir o ensino superior, entrelaçando diversas formas do conhecimento, e formar pessoas engajadas na transformação do País. Para os criadores, era importante reunir tudo que havia de mais moderno, para obter produções acadêmicas e pesquisas tecnológicas para melhorar a realidade brasileira $(\mathrm{UnB}, 2016)$.

Conforme expresso na lei, a Fundação tem personalidade jurídica e goza de autonomia didática, administrativa, financeira e disciplinar. Seu objetivo é criar e manter a Universidade de Brasília, instituição de ensino e pesquisa, em todos os ramos do saber e de divulgação científica, técnica e cultural. (BRASIL, 1961, arts. $1^{\circ}-3^{\circ}, 13^{\circ}$ ).

\begin{abstract}
Assim a UnB, ao buscar resgatar a sua identidade, a partir da redemocratização do país nos anos de 1980, inicia novo processo marcado, paradoxalmente, de um lado, pela defesa da indissociabilidade entre ensino, pesquisa e extensão e, de outro, por uma concepção gerencial articulada ao seu alto potencial de arrecadação e geração de recursos próprios, o que a distingue no conjunto das universidades federais (OLIVEIRA ET. AL, 2006, pg. 114).
\end{abstract}

As discussões na década de 1980 sobre a expansão da universidade de Brasília já incluíam aspectos físicos, dimensões da população universitária e o atendimento nas mais diversas necessidades científicas e culturais dos alunos. Esses detalhes eram importantes de serem definidos, uma vez que o crescimento do Distrito Federal e entorno, na época, foi o mais elevado do País nos últimos anos.

Com base em estudos sobre as necessidades de oferta, ensino e extensão, perfil e interesse da comunidade e o desenvolvimento econômico e demográfico das Regiões Administrativas do Distrito Federal e dos municípios do Goiás e Minas Gerais, foi possível identificar os locais em que seriam construídos os novos campi da UnB, os quais foram chamados de Regiões de Influência do Campus UnB (RICs UnB). Então, foi proposto a universidade atuar nas seguintes regiões (FUB, 2005, p. 5 e 6):

a) RIC I: Campus Universitário UnB - Plano Piloto (Campus Universitário Darcy Ribeiro), abrangendo as Regiões Administrativas de Brasília, Candangolândia, Cruzeiro, Guará, Lago Sul, Lago Norte, Núcleo 
Bandeirante, Sudoeste e Octogonal, Setor Complementar de Indústria e Abastecimento, Varjão e Park Way;

b) RIC II: Campus Universitário - Planaltina, abrangendo as Regiões Administrativas de Sobradinho, Planaltina, Brazlândia e Sobradinho II e os municípios de Formosa, Buritis, Planaltina de Goiás, Vila Boa e Água Fria de Goiás;

c) RIC III: Campus Universitário UnB - Ceilândia/Taguatinga, abrangendo as Regiões Administrativas de Ceilândia, Taguatinga, Riacho Fundo, Recanto das Emas, Samambaia e Águas Claras, e os municípios de Mimoso de Goiás, Padre Bernardo, Cocalzinho de Goiás, Pirenópolis, Águas Lindas, Corumbá de Goiás, Alexânia e Abadiânia;

d) RIC IV: Campus Universitário UnB - Gama, abrangendo as Regiões Administrativas de Gama, Santa Maria, São Sebastião, Paranoá, e os municípios de Cristalina, Luziânia, Valparaíso de Goiás, Novo Gama, Cidade Ocidental, Santo Antônio do Descoberto, Cabeceira Grande e Unaí.

O objetivo da criação desses novos campi vai além de a UnB assumir o seu papel de participação no desenvolvimento socioeconômico. Inclui também descentralizar o ensino, pesquisa e extensão, atender a demanda da população, estimular o desenvolvimento das cidades, melhorar as oportunidades de acesso ao ensino superior, assegurando a qualidade e a excelência acadêmica, e formar profissionais qualificados para a própria região (FUB, 2005).

Conforme o Anuário parcial de 2015, a UnB finalizou o semestre de 2014 com 154 cursos diurnos e 31 noturnos, 86 mestrados e 66 doutorados. Foram oferecidas 8.308 vagas do vestibular e PAS, ingressaram 10.689 alunos além do vestibular, PAS e outras formas de ingresso. Os alunos registrados regulares na graduação foram 36.372 e 4.022 alunos concluintes e os discentes regulares da pós-graduação foram 7.509 e 1.639 concluintes no ano de 2014.

Figura 2- Evolução universitária 2010 a 2014

\begin{tabular}{|c|c|c|c|c|c|}
\hline \multirow[b]{2}{*}{ Ano } & \multicolumn{2}{|c|}{ Discentes } & \multirow[b]{2}{*}{ Docentes } & \multirow{2}{*}{$\begin{array}{c}\text { Técnico- } \\
\text { Administrativos }\end{array}$} & \multirow[b]{2}{*}{ Total } \\
\hline & $\begin{array}{c}\text { Alunos de } \\
\text { Graduação }^{(1)}\end{array}$ & $\begin{array}{l}\text { Alunos de Pós- } \\
\text { Graduação }^{(2)}\end{array}$ & & & \\
\hline 2010 & 31.076 & 5.590 & 2.074 & 2.448 & 41.188 \\
\hline 2011 & 31.496 & 6.582 & 2.279 & 2.629 & 42.986 \\
\hline 2012 & 32.516 & 6.885 & 2.355 & 2.725 & 44.481 \\
\hline 2013 & 34.453 & 7.394 & 2.663 & 2.596 & 47.106 \\
\hline 2014 & 36.372 & 7.926 & 2.695 & 2.623 & 49.616 \\
\hline
\end{tabular}

Fonte: UnB (2015)

A estrutura dos cursos oferecidos na UnB é feita por meios dos Institutos e Faculdades, os quais estão relacionados no quadro abaixo: 
Quadro 1- Relação das Faculdades e cursos da UnB

\begin{tabular}{|c|c|c|c|}
\hline $\begin{array}{c}\text { Faculdades e } \\
\text { Institutos } \\
\end{array}$ & Cursos & $\begin{array}{c}\text { Faculdades e } \\
\text { Institutos } \\
\end{array}$ & Cursos \\
\hline \multirow{9}{*}{ Cursos a Distância } & $\begin{array}{l}\text { Administração } \\
\text { Pública }\end{array}$ & \multirow{6}{*}{$\begin{array}{l}\text { Faculdade UnB } \\
\text { Ceilândia - FCE }\end{array}$} & Enfermagem \\
\hline & Artes Visuais & & Farmácia \\
\hline & Biologia & & Fisioterapia \\
\hline & Educação Física & & Fonoaudiologia \\
\hline & Geografia & & Saúde Coletiva \\
\hline & Letras & & $\begin{array}{l}\text { Terapia } \\
\text { Ocupacional }\end{array}$ \\
\hline & Música & \multirow{5}{*}{$\begin{array}{l}\text { Faculdade UnB } \\
\text { Gama-FGA }\end{array}$} & Automotiva \\
\hline & Pedagogia & & Aeroespacial \\
\hline & Teatro & & Eletrônica \\
\hline \multirow{3}{*}{$\begin{array}{c}\text { Faculdade de } \\
\text { Agronomia e } \\
\text { Medicina Veterinária - } \\
\text { FAV }\end{array}$} & $\begin{array}{l}\text { Medicina } \\
\text { Veterinária }\end{array}$ & & Energia \\
\hline & $\begin{array}{l}\text { Gestão do } \\
\text { Agronegócio }\end{array}$ & & Software \\
\hline & Agronomia & \multirow{4}{*}{$\begin{array}{l}\text { Faculdade UnB } \\
\text { Planaltina - FUP }\end{array}$} & $\begin{array}{l}\text { Gestão } \\
\text { Ambiental }\end{array}$ \\
\hline $\begin{array}{c}\text { Faculdade de } \\
\text { Arquitetura e } \\
\text { Urbanismo - FAU }\end{array}$ & $\begin{array}{l}\text { Arquitetura e } \\
\text { Urbanismo }\end{array}$ & & $\begin{array}{l}\text { Gestão do } \\
\text { Agronegócio }\end{array}$ \\
\hline \multirow{3}{*}{$\begin{array}{l}\text { Faculdade de Ciências } \\
\text { da Informação - FCI }\end{array}$} & Biblioteconomia & & $\begin{array}{l}\text { Ciências } \\
\text { Naturais }\end{array}$ \\
\hline & Museologia & & $\begin{array}{l}\text { Educação do } \\
\text { Campo }\end{array}$ \\
\hline & Arquivologia & \multirow[b]{2}{*}{$\begin{array}{l}\text { Instituto de Artes - } \\
\text { IdA }\end{array}$} & Artes Cênicas \\
\hline $\begin{array}{c}\text { Faculdade de Ciências } \\
\text { da Saúde -FS }\end{array}$ & Enfermagem & & Artes Visuais \\
\hline \multirow{4}{*}{$\begin{array}{l}\text { Faculdade de Ciências } \\
\text { da Saúde -FS }\end{array}$} & Saúde Coletiva & \multirow{2}{*}{$\begin{array}{c}\text { Instituto de Artes - } \\
\text { IdA }\end{array}$} & $\begin{array}{l}\text { Desenho } \\
\text { Industrial }\end{array}$ \\
\hline & Farmácia & & Música \\
\hline & Nutrição & \multirow{2}{*}{$\begin{array}{c}\text { Instituto de } \\
\text { Ciências } \\
\text { Biológicas - IB }\end{array}$} & $\begin{array}{l}\text { Ciências } \\
\text { Biológicas }\end{array}$ \\
\hline & Odontologia & & Biotecnologia \\
\hline \multirow{5}{*}{$\begin{array}{c}\text { Faculdade de } \\
\text { Comunicação - FAC }\end{array}$} & Audiovisual & \multirow{4}{*}{$\begin{array}{c}\text { Instituto de } \\
\text { Ciências Exatas - } \\
\text { IE }\end{array}$} & Estatística \\
\hline & $\begin{array}{l}\text { Comunicação } \\
\text { Organizacional }\end{array}$ & & $\begin{array}{l}\text { Ciência da } \\
\text { Computação }\end{array}$ \\
\hline & Jornalismo & & Informática \\
\hline & $\begin{array}{l}\text { Publicidade e } \\
\text { Propaganda }\end{array}$ & & Matemática \\
\hline & $\begin{array}{l}\text { Comunicação } \\
\text { Social }\end{array}$ & \multirow{2}{*}{$\begin{array}{c}\text { Instituto de } \\
\text { Ciências Humanas } \\
\text { - IH }\end{array}$} & Filosofia \\
\hline $\begin{array}{c}\text { Faculdade de Direito - } \\
\text { FD }\end{array}$ & Direito & & Geografia \\
\hline
\end{tabular}




\begin{tabular}{|c|c|c|c|}
\hline $\begin{array}{l}\text { Faculdades e } \\
\text { Institutos }\end{array}$ & Cursos & $\begin{array}{l}\text { Faculdades e } \\
\text { Institutos }\end{array}$ & Cursos \\
\hline \multirow{4}{*}{$\begin{array}{c}\text { Faculdade de } \\
\text { Economia, } \\
\text { Administração e } \\
\text { Contabilidade - FACE }\end{array}$} & Administração & & História \\
\hline & Contabilidade & & Serviço Social \\
\hline & Economia & $\begin{array}{c}\text { Instituto de } \\
\text { Ciências Políticas } \\
\text { - IPOL } \\
\end{array}$ & $\begin{array}{l}\text { Ciências } \\
\text { Políticas }\end{array}$ \\
\hline & $\begin{array}{l}\text { Gestão de Políticas } \\
\text { Públicas }\end{array}$ & \multirow{3}{*}{$\begin{array}{c}\text { Instituto de } \\
\text { Ciências Sociais - } \\
\text { ICS }\end{array}$} & Antropologia \\
\hline $\begin{array}{c}\text { Faculdade de } \\
\text { Educação-FE }\end{array}$ & Pedagogia & & Sociologia \\
\hline $\begin{array}{c}\text { Faculdade de } \\
\text { Educação Física -FEF }\end{array}$ & Educação Física & & Ciências Sociais \\
\hline $\begin{array}{c}\text { Faculdade de } \\
\text { Medicina-FM }\end{array}$ & Medicina & $\begin{array}{c}\text { Instituto de Física } \\
\text { - IF }\end{array}$ & Física \\
\hline \multirow{9}{*}{$\begin{array}{l}\text { Faculdade de } \\
\text { Tecnologia - FT }\end{array}$} & Engenharia Elétrica & \multirow{3}{*}{$\begin{array}{c}\text { Instituto de } \\
\text { Geociências - IG }\end{array}$} & Geologia \\
\hline & $\begin{array}{l}\text { Engenharia de } \\
\text { Redes de } \\
\text { Comunicação }\end{array}$ & & Geofísica \\
\hline & $\begin{array}{l}\text { Engenharia de } \\
\text { Computação }\end{array}$ & & $\begin{array}{l}\text { Ciências } \\
\text { Ambientais }\end{array}$ \\
\hline & $\begin{array}{l}\text { Engenharia } \\
\text { Florestal }\end{array}$ & \multirow{2}{*}{$\begin{array}{c}\text { Instituto de Letras } \\
\text { - IL }\end{array}$} & Letras \\
\hline & $\begin{array}{l}\text { Engenharia } \\
\text { Mecânica }\end{array}$ & & Tradução \\
\hline & $\begin{array}{l}\text { Engenharia de } \\
\text { Controle e } \\
\text { Automação }\end{array}$ & $\begin{array}{c}\text { Instituto de } \\
\text { Psicologia - IP }\end{array}$ & Psicologia \\
\hline & Engenharia Civil & \multirow{3}{*}{$\begin{array}{c}\text { Instituto de } \\
\text { Química - IQ }\end{array}$} & Química \\
\hline & $\begin{array}{l}\text { Engenharia } \\
\text { Ambiental }\end{array}$ & & $\begin{array}{l}\text { Engenharia } \\
\text { Química }\end{array}$ \\
\hline & $\begin{array}{l}\text { Engenharia de } \\
\text { Produção }\end{array}$ & & $\begin{array}{l}\text { Química } \\
\text { Tecnológica }\end{array}$ \\
\hline $\begin{array}{l}\text { Centro de Excelência } \\
\text { em Turismo - CET }\end{array}$ & Turismo & $\begin{array}{c}\text { Instituto de } \\
\text { Relações } \\
\text { Internacionais - } \\
\text { IREL } \\
\end{array}$ & $\begin{array}{l}\text { Relações } \\
\text { Internacionais }\end{array}$ \\
\hline
\end{tabular}

Fonte: Elaborado pela autora com base no site da Universidade de Brasília

Em relação aos números relacionados à evasão, é preciso destacar que, de acordo com a FUB (2008), no período de 2001 a 2005, 42\% dos alunos saíram da instituição. E isso representa uma demanda de ação imediata, a qual requer soluções estruturais. Além disso, os números de trancamentos, reprovações e abandonos são muito elevados, o que contribui para uma maior permanência na instituição de em média $20 \%$ a mais do tempo previsto para a conclusão do ensino superior. 
As possíveis causas apontadas da evasão são: a falta de orientação acadêmica, a necessidade de conciliar trabalho com estudos, desmotivação, falta de desempenho mínimo exigido, deficiências na formação do ensino médio, desinteresse pelo curso ocasionado pela decisão precoce para entrar na universidade e a falta da qualidade das disciplinas, que na maioria das vezes são ministradas por professores inexperientes, entre outras (FUB, 2008).

Vale comentar que, para Oliveira et.al, (2006, pg. 113) ao longo da história das universidades mundiais, não há indícios de que existe uma concepção única de universidade, mas há alguns elementos que caracterizam o modelo universal ou original em uma universidade. A UnB contribui com a identificação de alguns desses elementos e influenciou no desenvolvimento e estruturação de outras universidades federais. $\mathrm{O}$ fato de que sua criação, trajetória, estruturação e consolidação passou pelos mais "diferentes momentos econômicos, políticos, sociais e culturais da sociedade brasileira indicam que a UnB traz uma contribuição importante para uma reflexão acerca do que vem a ser a universidade brasileira".

\subsection{O Processo de Reintegração}

$\mathrm{Na}$ Universidade de Brasília (UnB), a Reintegração é um processo administrativo interno no qual o aluno que abandona o curso, não tem rendimento acadêmico, reprova três vezes na mesma disciplina ou é jubilado do curso de graduação solicita retornar ao curso expondo os motivos que o levaram ao desligamento e o porquê de desejar retornar à universidade.

Para que os processos de solicitações dos alunos fossem avaliados, foi criada uma Comissão de Acompanhamento e Orientação (CAO), composta por professores dos departamentos dos cursos da UnB, que teriam o comprometimento de analisar e deliberar sobre esses processos.

A CAO analisou os processos de reintegração desde o ano de 2004 até dezembro de 2014, quando foi alterada a forma da solicitação de reintegração por meio de processos administrativos para o cumprimento de requisitos e prazos do edital de reintegração.

A análise de reintegração de ex-alunos, realizada pela Comissão de Acompanhamento e Orientação (CAO) e pela Câmara de Ensino de 
Graduação (CEG), refere-se ao processo para o retorno de alunos desligados e ao acompanhamento de alunos em risco de desligamento. Há uma preocupação da Universidade com o crescente número de alunos desligados e em risco de desligamento da Universidade. Por isso, as ações futuras estão voltadas para prevenir situações que levem à evasão de discentes. Atualmente, há estudos na universidade que evidenciam a quantidade de alunos que conseguem ser reintegrados, a taxa de sucesso na conclusão do curso desses alunos e as principais causas de desligamento. Com base nesses estudos sobre reintegração, a UnB está delineando estratégias que auxiliem na permanência do discente e na conclusão do curso. Além da reestruturação no apoio psicopedagógico, está em curso a adequação do embasamento legal do processo de reintegração, de acolhimento ao aluno em risco de desligamento e do aluno em condição. Uma comissão da CEG foi especialmente designada para tratar do processo de reintegração. A intenção é organizar o processo de reintegração e torná-lo sistematizado. Uma das ações previstas com a mudança na legislação é a abertura de editais para solicitação de reintegração, com prazos pré-estabelecidos e com regras objetivas e bem definidas aos ex-alunos que desejam retornar à UnB (UnB, 2014d, p. 70).

A comissão tinha como informações básicas para a análise e deliberação do processo o nome e matrícula do aluno, o curso de graduação de que foi desligado, a habilitação (se bacharel ou licenciado), o turno (se diurno ou noturno), o período do semestre em que foi desligado e o tempo de permanência na instituição, a forma de ingresso, se cotista ou não, a quantidade de créditos e de semestre que o aluno havia cursado e quantos créditos faltavam por semestre para concluir, o motivo do desligamento (abandono, não cumpriu condição, jubilamento ou por reprovação em três vezes na mesma disciplina), o quantitativo de solicitações já feitas pelo mesmo aluno (se era o primeiro processo ou a terceira ou quarta tentativa de retorno), e a decisão do colegiado.

Com base nessas informações, a CAO decidia se era a favor ou contra o reingresso do aluno. Havia casos em que o Colegiado do Curso deliberava contrariamente ao retomo ao curso e, com isso, os membros da comissão poderiam também optar em não reintegrar o aluno, apesar das justificativas e documentações apresentadas.

Caso a comissão decidisse favoravelmente ao discente, tal processo deveria aguardar uma terceira decisão, por ter tido pareceres contrários, cabendo à CEG encaminhar o processo a um relator e, até então, o aluno deveria aguardar a decisão final a ser tomada.

Destaca-se que, na época, os processos eram analisados por ordem de chegada, tanto na CAO como na CEG. Devido ao elevado número de desligamentos e 
solicitações de reintegrações, alguns alunos ficavam de um a dois semestres sem retornar aos estudos.

Os tramites dos processos administrativos de solicitação de reintegração dos alunos desligados se dava da seguinte maneira:

* O aluno entregava seu requerimento (processo) no Posto Avançando do seu curso;

* O Posto Avançado montava o processo conforme as instruções e documentações necessárias para a análise.

* O processo, então, era enviado ao coordenador do curso para que fosse feita a análise e a emissão de parecer do colegiado do curso de graduação - favorável ou não à reintegração daquele aluno.

* Se o colegiado fosse de acordo com o retorno desse aluno, eles já elaboravam um plano de estudos (planejamento das disciplinas a serem cursadas) o qual o aluno deveria cumprir, caso a CAO também estivesse de acordo com a reintegração.

* O processo então era enviado à CAO/DEG para análise e deliberação da comissão em suas reuniões.

* O processo deveria ser homologado na Câmara de Ensino de Graduação (CEG) para posterior finalização do processo e ciência do aluno.

Figura 3- Trâmite do processo de reintegração

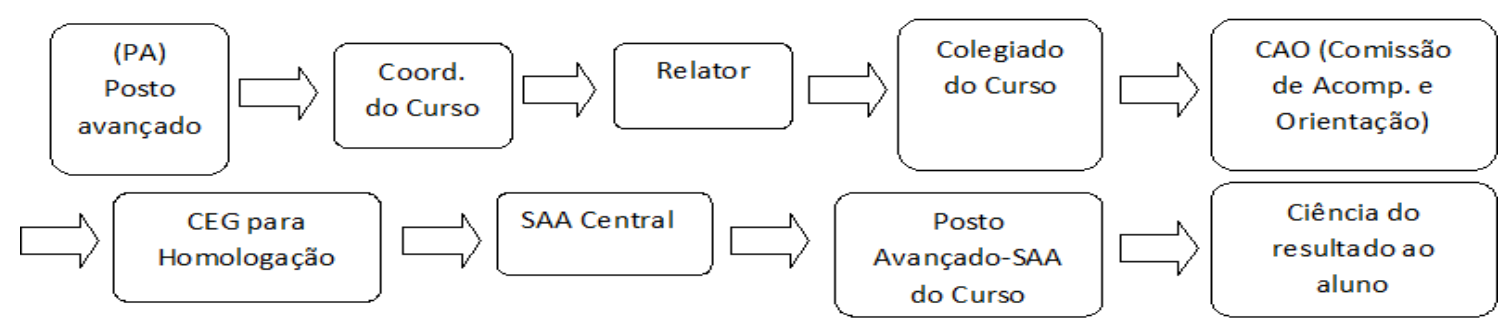

Fonte: Elaborado pela autora.

Ao analisar os processos de reintegração, percebeu-se que, ao longo dos anos, até 2014, os principais motivos apresentados pelos alunos para justificar o desligamento da universidade eram os elencados abaixo. 
Infelizmente não é possível obter o gráfico da série histórica dos motivos de desligamento, devido ao fato de a pesquisadora não poder ter acesso ao quantitativo da entrada de processos e também por esses dados estarem disponíveis apenas para a equipe responsável por organizar os processos e ajudar a comissão na hora da análise e deliberação do processo.

- Dificuldades em conciliar trabalho e estudos;

* Problemas familiares/pessoais;

* Problemas econômicos/financeiros;

Problemas de saúde;

* Problemas psicológicos e/ou psiquiátricos;

* Problemas acadêmicos;

* Desconhecimento de regras;

- Dificuldade na disciplina;

* Atribuição de prioridade a outros cursos.

Muitos desses motivos, como se pode observar, vão além de cumprir as regras acadêmicas estabelecidas pela universidade. Infelizmente, em muitos casos, acontecem problemas na vida pessoal dos alunos, tais como de ordem familiar, pessoal, econômica, saúde, psicológica, etc. Pode-se citar como exemplo: pais se divorciando, familiares se envolvendo com drogas ou bebidas, descobertas de doenças graves, gravidez inesperada, necessidade de iniciar uma atividade laboral, transtornos comportamentais.

Os Coordenadores de Curso, por falta de instrumentos que lhes permitam o acompanhamento do desempenho acadêmico dos alunos matriculados em seu curso, ou por falta de um projeto que considere o acompanhamento não só do desempenho do aluno, mas de apoio psicopedagógico, enfrentam o fenômeno da exclusão, como aquele diretamente ligado aos fatores relacionados ao aluno, principalmente os de natureza socioeconômica, que refletem no tipo de conhecimentos adquiridos no ensino médio. Frente a esses fatores, os coordenadores nada podem fazer, a não ser esperar que o aluno se adapte à estrutura universitária ou, não se sentindo capaz, abandone o curso (VELOSO e ALMEIDA, 200, p.139).

A partir do ano de 2015, ficou deliberado que a decisão do retorno do aluno caberia ao Colegiado do Curso de Graduação e que os recursos da decisão deveriam ser encaminhados à CEG para análise e deliberação final do processo de reintegração (UnB, 2014b). 
Os interessados teriam que acompanhar o edital conforme o cronograma definido para não perder os prazos da solicitação, entrega dos formulários exigidos e toda a documentação, uma vez que a falta de qualquer um dos requisitos pode acarretar o indeferimento do pedido de reintegração.

Muitas pessoas já analisaram os processos de reintegrações nas mais diversas instâncias de deliberação. Assim, não se pode mensurar quantas foram as tomadas de decisões já realizadas, suas consequências no retorno ou não de cada aluno que entrou com o pedido de reingresso à universidade e em qual medida a racionalidade da decisão de cada membro de Comissão ou Colegiado influenciou na dinâmica dos quantitativos dos dados da entrada e saída desses alunos.

No entanto, além do processo decisório das instâncias que deliberam favoravelmente ou não à reintegração do aluno, há uma decisão importante que é a do próprio aluno de dar entrada com o pedido de reintegração. Embora essa decisão não seja determinante do resultado do processo, ela é fundamental para o possível retorno do aluno à universidade, pois é o primeiro passo. Os dados desta pesquisa também não permitem mensurar a quantidade de pedidos de reintegração (apenas os próprios casos de desligamento e de reintegração). Ainda assim, a decisão do aluno de solicitar a reintegração é uma etapa importante do processo.

Cabe esclarecer que o perfil que se busca estudar neste trabalho não é o mesmo perfil analisado pela Universidade na decisão final de reintegrar ou não (dadas as informações básicas para a análise e deliberação do processo, descritas anteriormente). Trata-se realmente do perfil do aluno reintegrado e reintegrado formado, mas sem perder de vista que os dados se referem a alunos que, primeiramente, tomaram a decisão de solicitar a reintegração.

\subsubsection{Instruções Normativas sobre o desligamento e a reintegração dos alunos de graduação na UnB}

A Universidade de Brasília (UnB) estabelece procedimentos e orientações por meio do Estatuto e Regimento Geral, Instruções Normativas e Guias de Calouros sobre como proceder em casos de alunos que estão em risco de desligamento ou até mesmo desligados da instituição. A política da instituição é de incentivar a permanência e o 
desenvolvimento desses discentes nos respectivos cursos de graduação, reduzindo assim o número de evasão da Universidade.

É importante frisar que serão destacadas as duas últimas Instruções Normativas relacionadas ao assunto de desligamento e reintegração, uma vez que no início do ano de 2015 foi adotada uma nova regra para a reintegração dos alunos da UnB e também pelo fato de que os dados coletados para esta pesquisa foram dos anos de 2000 a 2014, sendo, portanto, necessário explicitar as duas Instruções Normativas.

Está previsto no inciso IX do artigo $7^{\circ}$ do Estatuto e Regimento Geral da UnB que cabe ao Conselho de Ensino, Pesquisa e Extensão (CEPE) regulamentar sobre o desligamento e a reintegração dos alunos da universidade. Diante disso, o CEPE criou a Resolução $\mathrm{n}^{\circ}$. 041/2004, que trata das condições para o desligamento e orientação acadêmica dos estudantes de graduação (UnB, 2004).

A resolução do CEPE ressalta que compete à Comissão de Acompanhamento e Orientação (CAO) do Decanato de Ensino de Graduação (DEG), identificar, orientar e encaminhar para o estudante a orientação de desligamento (UnB, 2004).

O Decanato de Ensino de Graduação tem como função coordenar, avaliar e supervisionar o ensino de graduação, com políticas públicas estudantis que promovem e aperfeiçoam a qualidade do ensino superior. O DEG é assessorado pela Câmara de Ensino de Graduação (CEG), que tem como objetivo administrar as atividades universitárias de ensino de graduação, assim como elaborar normas complementares ao Regimento Geral da UnB (UnB, 2012a).

A CAO foi criada pela Resolução nº 041/2004 do CEPE para apoiar a Câmara de Ensino de Graduação no que diz respeito aos pedidos de reintegração, aos alunos sob o risco de desligamento, à orientação acadêmica e à permanência desses discentes na UnB. A CEG, no uso de suas atribuições, regulamentou Instruções Normativas que tratam sobre esses assuntos.

A Instrução Normativa (IN) $\mathrm{n}^{\circ}$. 001/2012 foi utilizada, até o final do ano de 2014, como base para os pedidos de reintegração, orientação acadêmica e risco de desligamento. A IN no . 001/2014 entrou em vigor no início do ano de 2015 para regulamentar os novos procedimentos adotados, devido ao grande número de processos de reintegração encaminhados aos Coordenadores de Curso de Graduação para análise e elaboração de Plano de Acompanhamento Acadêmico. 
Cabe destacar que essa nova instrução reformulou apenas o Capítulo III da instrução anterior (que trata sobre a reintegração e cuja reformulação será abordada mais adiante), de modo que as demais disposições continuam sendo válidas. Além disso, o Plano de Estudos mencionado na instrução de 2012 passou a ser chamado de Plano de Acompanhamento Acadêmico. Com isso, a responsabilidade de elaborar o plano passou a caber ao professor orientador, e não mais à Comissão.

\subsubsection{O risco de desligamento e o desligado}

O Artigo $5^{\circ}$ da IN $n^{\circ}$. 001/2012 cita que a Secretaria de Administração Acadêmica (SAA) é responsável por enviar aos coordenadores de Graduação a relação dos alunos desligados por não rendimento acadêmico ou que estão em risco de desligamento (UnB, 2012b).

Portanto, o aluno estará sob o risco de desligamento, conforme o Artigo $7^{\circ}$ da Instrução Normativa $n^{\circ}$ 001/2012 da CEG, quando:

For reprovado 2 (duas) vezes na mesma disciplina obrigatória;

* Não for aprovado em 4 (quatro) disciplinas do seu curso, nos 2 (dois) períodos letivos sucessivos;

* Chegar ao último período letivo permitido no projeto pedagógico e não poder concluir o curso (UnB, 2012b).

De acordo com as IN n ${ }^{\circ}$ 001/2012 e 001/2014 da CEG, o discente que for reintegrado deverá ser acompanhado pelo professor orientador e deixará de estar sob o risco de desligamento se cumprir uma das seguintes condições:

Conseguir a aprovação nas disciplinas obrigatórias em que o (a) discente teve duas reprovações;

* Conseguir a aprovação no número mínimo de créditos estabelecido pelo curso, nos próximos dois períodos letivos subsequentes;

* Cumprir o plano de acompanhamento acadêmico estipulado por um (a) professor (a) orientador (a): 
- O plano de acompanhamento acadêmico é o planejamento das disciplinas a serem cursadas com probabilidade de êxito pelo discente (UnB, 2014b, 2012b).

O Plano de Acompanhamento Acadêmico, anteriormente chamado de Plano de Estudos, é um instrumento utilizado para auxiliar os alunos quando não é possível cumprir com um dos requisitos estipulados pelas regras da UnB. O plano é elaborado em acordo com o professor (a) orientador (a) do curso. Conforme a IN n ${ }^{\circ}$. 001/2014, o aluno reintegrado deverá ter a aprovação, em dois semestres consecutivos, de no mínimo quatro disciplinas obrigatórias e/ou optativas do Curso (UnB, 2014b). Porém, dependendo da situação individual de cada aluno, por meio do Plano de Acompanhamento, o discente não precisa necessariamente cumprir a quantidade mínima de créditos estipulados para cada curso.

A resolução $n^{\circ} .41 / 2004$ estabelece que a orientação acadêmica é um diálogo continuado, que vai além da vida acadêmica, que apresenta qualidades e permite o aproveitamento das experiências e a compreensão das relações entre alunos e professores. A orientação acadêmica é assegurada a todos os alunos até concluírem pelo menos $50 \%$ (cinquenta por cento) dos créditos exigidos pelo curso, inclusive aos alunos em risco de desligamento.

Pelo Artigo $8^{\circ}$ da Resolução nº 041/2004 da CEPE, o discente de graduação será desligado da UnB nos seguintes casos:

Desligamento por ABANDONO DE CURSO: é quando o discente da UnB não efetua matrícula em disciplinas ou não cursa nenhuma disciplina nos 2 (dois) períodos letivos sucessivos;

* Desligamento VOLUNTÁRIO: ocorre quando o estudante, por iniciativa própria, desiste do vínculo com o curso;

* Desligamento por JUBILAMENTO: acontece quando o discente esgota o tempo máximo permitido para a conclusão do curso;

- Desligamento por RENDIMENTO ACADÊMICO: aplica-se ao aluno que não tenha cursado com aprovação 4 (quatro) disciplinas do curso nos 2 (dois) períodos letivos sucessivos, que tenha reprovado 3 (três) vezes na mesma disciplina obrigatória ou que não tenha cumprido condição imposta. 
Quando não cursa o mínimo de créditos do curso;

Quando não cumpre o plano de acompanhamento acadêmico elaborado em conjunto com o orientador e acordado pelo aluno (UnB, 2004).

Conforme o Artigo $125^{\circ}$ do Estatuto e Regimento Geral da UnB, o estudante do curso regular de graduação será desligado quando:

* Não obtiver aproveitamento em 4 (quatro) disciplinas do curso em 2 (dois) períodos letivos sucessivos;

- Reprovar 3 (três) vezes em disciplina obrigatória do curso;

* Estiver nos critérios eliminatórios específicos do curso, definidos pelo CEPE;

* Incorrer em infração disciplinar junto com expulsão, conforme o Código de Ética;

* Não concluir o curso no prazo máximo estabelecido (UnB, 2011b).

O risco de desligamento é o semestre anterior ao aluno ser desligado da UnB. Portanto, o aluno não é desligado de imediato da universidade, ele é alertado pelos coordenadores e/ou professores orientadores do curso de que está sob a condição de cumprir as normas, para que não seja preciso chegar ao nível do desligamento e, assim, não necessitar de passar por todo o processo burocrático interno do pedido de reintegração que será tratado adiante.

\subsubsection{A reintegração e a solicitação de reintegração}

Conforme a nova IN da CEG $n^{\circ} 001 / 2014$, utilizada a partir do ano de 2015, a solicitação de reintegração deverá ser realizada no prazo máximo de um ano a partir do semestre em que o discente foi desligado. Assim, a partir do momento em que o aluno recebe a informação de que está desligado da UnB, ele poderá solicitar a reintegração no Posto Avançado da SAA do respectivo curso, que encaminhará a solicitação à coordenação do curso, obedecendo aos critérios e cronograma constantes em edital do DEG (UnB, 2014b, 2012b).

Destaca-se que todo o andamento do processo de reintegração é exógeno ao aluno, ou seja, o aluno não interfere no resultado. Ele pode acompanhar o andamento do 
processo, mas não pode interferir, cabendo apenas aos responsáveis tomar a decisão do retorno ou não.

A partir dessa nova Instrução Normativa, serão permitidas no máximo duas reintegrações na UnB. Cabem ao Colegiado do Curso a análise e deliberação do processo de reintegração dos discentes desligados que respeitem e apresentem as seguintes premissas abaixo:

Justificativas comprovando que a situação que o levou ao desligamento foi sanada;

* Documentos que justifiquem problemas de saúde, mediante atestado ou relatório médico;

* Documentação formal que justifique outros problemas plausíveis de comprovação;

* Quaisquer outros documentos necessários que poderão ser requisitados pelo Colegiado de Curso de Graduação;

* Enquadramento do aluno na situação de ter poucos créditos necessários para concluir o curso de graduação dentro do período máximo de permanência no Curso;

* Enquadramento do discente no caso de estar afastado por um período não superior a 1 (um) ano (UnB, 2014b).

Em seu Artigo $4^{\circ}$, a IN $n^{\circ}$. 001/2014 expõe que, se a reintegração for recomendada pelo Colegiado do Curso, será indicado um professor orientador e será elaborado um plano de acompanhamento acadêmico, conforme a situação acadêmica e a justificativa apresentada pelo discente, e caso necessário ele ou ela poderá solicitar a substituição do professor orientador (UnB, 2014b).

Segundo o Artigo $5^{\circ}$, para todos os discentes que conseguirem a reintegração será necessário cumprir a condição em dois semestres consecutivos, a aprovação em no mínimo 4 (quatro) disciplinas obrigatórias e/ou optativas do Curso (UnB, 2014b).

Os Artigos $6^{\circ}$ e $7^{\circ}$ da IN $n^{\circ}$. 001/2014 da CEG estabelecem que, conforme o cronograma estabelecido em edital pelo DEG, o Colegiado de Curso de Graduação encaminhará todos os processos analisados à SAA para as devidas providências. No que 
diz respeito aos recursos referentes à decisão do Colegiado de Curso de Graduação, estes deverão ser encaminhados à CEG (UnB, 2014b).

Cabe destacar que os Artigos $10^{\circ}$ ao $14^{\circ}$ da IN da CEG $n^{\circ} .001 / 2012$, utilizada até o final do ano de 2014, determinavam que a reintegração deveria ser solicitada no prazo máximo de dois anos (e não um), a partir do semestre em que o discente foi desligado. Além disso, desde o momento em que o aluno solicitava a reintegração no Posto Avançado da SAA do respectivo curso, o Colegiado fazia a análise e parecer técnico do pedido de reintegração e posteriormente encaminhava os pedidos à Comissão de Acompanhamento e Orientação, uma vez que era de competência da CAO analisar também os processos de reintegração.

A CAO poderia recomendar à CEG a reintegração do aluno, desde que o discente apresentasse exposição de motivos, comprovando que a situação que o levou ao desligamento foi sanada e que era possível seguir com o andamento do curso normalmente, ou também em casos de alunos que faltassem poucos créditos necessários para concluir o curso de graduação, ou até mesmo discentes que não estivessem afastados do curso por um período não superior a 4 (quatro) semestres letivos (UnB, 2012b).

Em casos em que ambas as instâncias concordassem com a reintegração do discente, seria indicado um professor orientador e elaborado um plano de estudos (agora Plano de Acompanhamento Acadêmico), conforme a situação acadêmica e a justificativa apresentada pelo aluno. Caso houvesse divergência dos pareceres, o processo era encaminhado à CEG para análise e parecer final da solicitação.

Como se pode observar, o processo de reintegração de um ex-aluno passa por diversas etapas de tomada de decisão, dos agentes públicos envolvidos no processo, mas também do próprio requerente. Desde a escolha do aluno de pedir a reintegração, com base nos critérios estabelecidos pelas normativas, até a decisão final por reintegrar ou não o discente, passando pela análise do pedido, inúmeros são os fatores que estão relacionados a esse processo.

Destaca-se que todos têm papel importante nesse processo e que não basta às vezes o coordenador e o professor orientador saberem da real situação na qual o aluno se encontra, é preciso haver o interesse recíproco (do professor e do aluno) para que seja possível compartilhar as suas experiências e alcançar uma boa orientação acadêmica que acarretará bons resultados para a instituição. 


\subsubsection{Dados de Evasão dos últimos anos na UnB}

Sabe-se que o crescente número de alunos desligados e em risco de desligamento é preocupante e o Plano de Desenvolvimento Institucional (PDI) dos anos 2014 - 2017 têm demonstrado essa preocupação. O objetivo é prevenir situações que levem os estudantes à evasão. Para tanto, houve uma reformulação na Instrução Normativa, em que se procede à abertura de edital para que os interessados no retorno à universidade deem entrada ao processo, de acordo com datas pré-estabelecidas e com as novas regras (UnB 2014d).

Nos anuários oficiais publicados pela UnB, foram feitos levantamentos do quantitativo de movimentação da universidade. Entende-se por movimentação não somente aqueles alunos que foram desligados por abandono, baixo rendimento ou jubilamento, mas também aqueles desligados por outros motivos, como falta de documentação, força de convênio, expulsão disciplinar, falecimento, decisão judicial, mudança de curso, transferências, trancamento geral de matrícula, entre outros. Os valores coletados nos anuários da UnB referem-se apenas aos desligamentos por abandono, falta de rendimento e jubilamento.

Todas essas informações foram geradas pelo Sistema de Informações Acadêmicas (SIGRA), que é utilizado para o controle e planejamento do curso. É também utilizado para o registro do ingresso (dados pessoais de alunos regulares e especiais, número de matrícula), o acompanhamento (emissão de histórico escolar, registro de menções, controle de trancamento de matrícula, grade horária, monitorias, concessão de créditos, trabalho final de curso - monografia) e o desligamento (confirmação de informações para emissão do diploma) dos discentes de graduação (UnB 2014a).

Os resultados abaixo são apenas um demonstrativo da quantidade de evasão dos anos de 2010, 2012 e 2013. Ressalta-se que não estão disponíveis ao público os dados de evasão para todos os anos, dificultando a análise confiável de uma evolução histórica do total de desligamentos. Quanto aos resultados do ano de 2014, não houve, até a presente data de finalização desta pesquisa, a divulgação completa do anuário da UnB, apenas a parcial.

Para uma melhor visualização, foi feito um gráfico dos três anos (2010, 2012 e 2013), com a soma do quantitativo de desligamentos de discentes de graduação das 
unidades acadêmicas da universidade. Os dados foram empilhados conforme a justificativa para o desligamento, o que permite uma melhor comparação entre si.

Figura 4- Número de discentes desligados da graduação por Instituto ou Faculdade da UnB $(2010,2012$ e 2013)

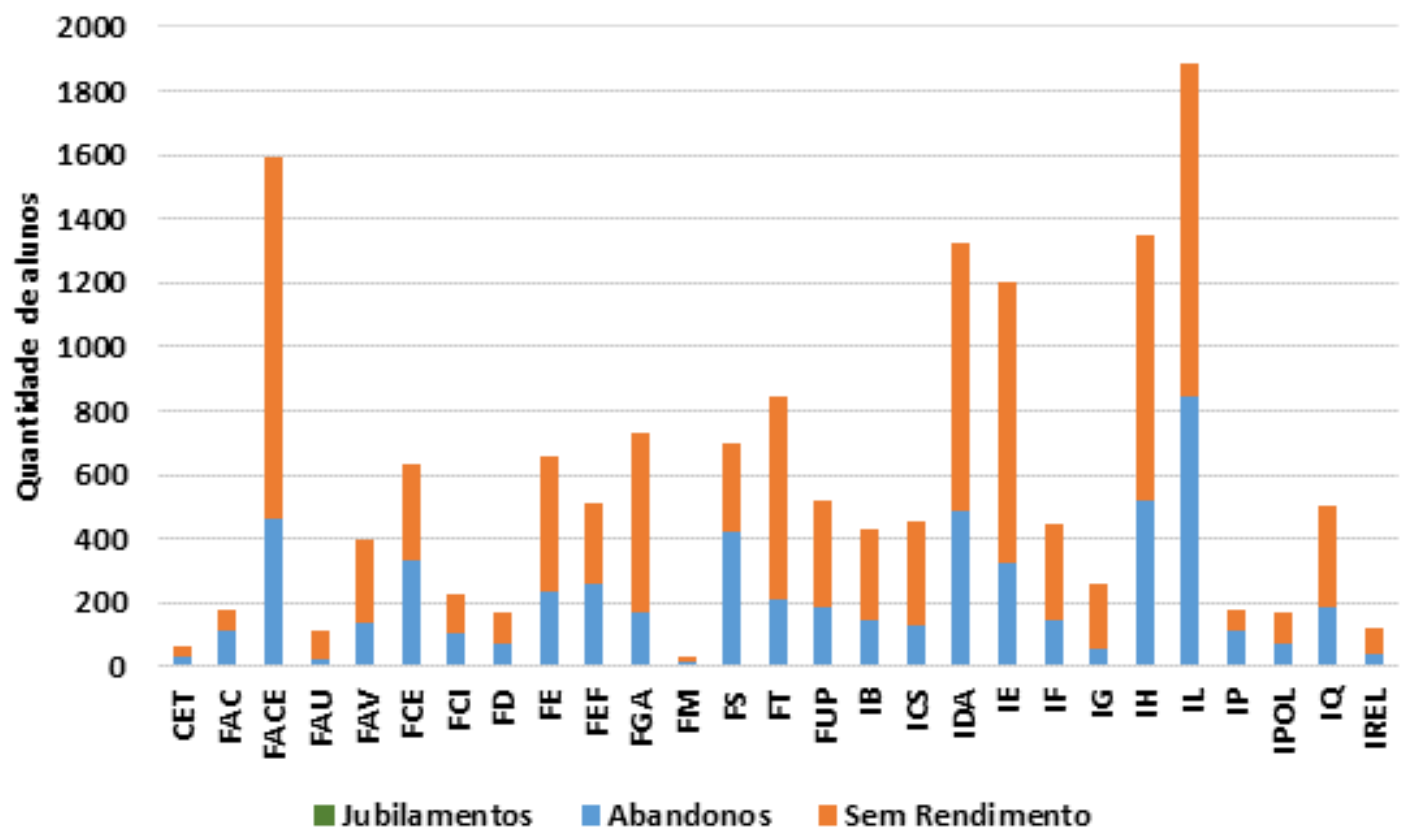

Fonte: UnB (2011a; 2013; 2014d)

O Anuário da UnB (2011a) descreve que houve um total de 3.248 (três mil, duzentos e quarenta e oito) alunos desligados nos cursos de graduação, referente ao ano de 2010. O quantitativo dos casos de jubilamento não é significativo, pois representa uma parcela muito reduzida, em relação ao total de desligados. Observa-se que são destacados nos três anos os altos índices de evasão da FACE, IDA, IE, IH e IL.

Para o ano de 2012 teve um total de 9.058 (nove mil e cinquenta e oito) alunos desligados nos cursos de graduação. Os números referentes aos casos de jubilamento não são significativos, pois representam uma parcela muito reduzida, em relação ao total de desligados (UNB 2013).

Os dados já são diferentes quando se trata do ano de 2013, pois a quantidade registrada de alunos que foram desligados nos cursos de graduação no ano de 2013 foi um total de 3.390 (três mil, trezentos e noventa), conforme o Anuário da UnB (2014c). 


\section{MÉTODOS E TÉCNICAS DE PESQUISA}

Para a realização deste trabalho, teve-se como base informações fornecidas pelo Centro de Informática da UnB (CPD). O grupo estudado é composto por uma população de um período de 15 anos (2000 a 2014), que consiste no total de 18.268 observações de casos de desligamento de discentes que estudaram nos quatros campi da Universidade de Brasília. Vale ressaltar que fazem parte do banco de dados todos os alunos desligados da instituição, independentemente de terem solicitado ou não a reintegração. Ou seja, o banco contempla aqueles alunos que conseguiram a reintegração, aqueles que não conseguiram e aqueles que sequer pediram.

Busca-se investigar assim quais são as características observáveis atribuídas aos estudantes que estão relacionadas com a probabilidade de reintegração e, em seguida, a mesma probabilidade desses alunos que conseguiram reintegrar concluir seus respectivos cursos. Para o atendimento dos objetivos desta pesquisa foi utilizado como método de análise um modelo de regressão logística binomial para traçar os perfis desses alunos que foram desligados da universidade.

\subsection{A Regressão Logística}

Nesta pesquisa, foram utilizados dois modelos de Regressão Logística, com a intenção de identificar o perfil dos discentes da Universidade de Brasília que são reintegrados, após serem desligados dos seus cursos de graduação.

Um dos primeiros estudos desenvolvido pelo Framingham Heart Study em parceria com a Universidade de Boston, em 1960, utilizou a regressão logística para analisar predições ou esclarecer a ocorrência de determinados fenômenos quando a variável dependente é categórica binária. Esse estudo ajudou a mensurar os fatores que desencadearam as doenças cardiovasculares associados a características pessoais como cor, idade, sexo, etc. e identificar doenças como: hipertensão, tabagismo, diabetes, entre outras (CORRAR, et al., 2009).

Uma das principais particularidades que distingue os modelos de regressão logística é o fato de a variável dependente ser dicotômica, ou seja, "sim" ou "não", "aceitar" ou "rejeitar", categórica binária (não métrica), por meio de variáveis independentes métricas. Por meio da regressão é possível identificar o melhor modelo, 
de acordo com o ajuste entre as variáveis relacionadas, e maximizar a verossimilhança da probabilidade da razão de chances ou OR (OddsRatio) que algo ocorra (CORRAR, ET AL.; HAIR, ET AL. 2009, 2005).

Para a verificação do ajuste do modelo é precisar analisar os valores dos testes de -2 Log Likelihood, R ${ }^{2}$ Nagelkerke e também o teste de Hosmer e Lemeshow. Porém, como os autores Corrar et al. (2009) destacam, a avaliação não deve ser feita de forma isolada e sim em conjunto, uma vez que os valores de um influenciam no dado de outro teste e juntos eles avaliam o ajuste do modelo.

O R² de Nagelkerke, na regressão logística, ao contrário da regressão linear, não representa a dimensão da variação total na variável dependente em detrimento das independentes. Apesar de ser similar ao $\mathrm{R}^{2}$ na regressão linear, esse $\mathrm{R}^{2}$ analisa a melhora ou não das predições ao comparar o modelo com um que ignore as variáveis independentes. Ele não poderá ser definido como a taxa de variação da probabilidade de um evento ocorrer (CORRAR et al., 2009).

Segundo Corrar et al. (2009), o teste de Hosmer e Lemeshow compara as predições do modelo com os dados observados. A ideia é verificar se há diferenças entre o que o modelo prevê e a realidade das observações. O ideal é que essas diferenças sejam as mínimas possíveis.

O nível de significância tem como objetivo validar o modelo estimado por meio de testes estatísticos, avaliando hipóteses. Adotam-se níveis de significância de 0,050 ou mais, dependendo do modelo - nestes modelos, em específico, foram adotados os níveis de $1 \%, 5 \%$ e $10 \%$. Para verificar o nível de significância, é preciso testar a influência que as variáveis independentes exercem significativamente ou não na variável dependente (CORRAR et al., 2009).

$\mathrm{Na}$ avaliação dos resultados, é preciso observar o sinal dos coeficientes $\beta$ das variáveis, uma vez que o sinal (positivo ou negativo) representa o impacto direto ou inverso das variáveis explicativas sobre a probabilidade da variável dependente e em que intensidade cada variável afeta a razão das chances do evento definido pelos modelos para esses discentes (FERREIRA et al., 2012; SANTOS e SILVA JÚNIOR, 2015).

\subsection{Construção dos Modelos}


Com a finalidade de melhor compreender as peculiaridades do universo dos discentes desligados e também de obter uma análise mais minuciosa dos dados obtidos, foram construídos 2 (dois) modelos, ambos binomiais. A finalidade de construir os modelos foi de determinar as variáveis explicativas que, depois de controlados os efeitos das outras, se correlacionem com o perfil dos alunos reintegrados. Os modelos foram denominados da seguinte forma:

1) Modelo "Reintegrados";

2) Modelo "Reintegrados e Formados";

Dessa forma, os modelos contêm resultados da razão de chances, estimados com algumas variáveis explicativas. As variáveis dependentes binárias se correspondem da seguinte maneira:

Reintegrados $(\mathrm{R})$ : variável dependente do $1^{\circ}$ modelo

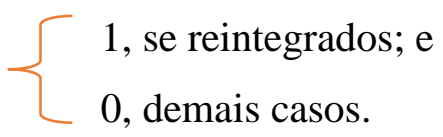

* Reintegrados e Formados (RF): variável dependente do $2^{\circ}$ modelo

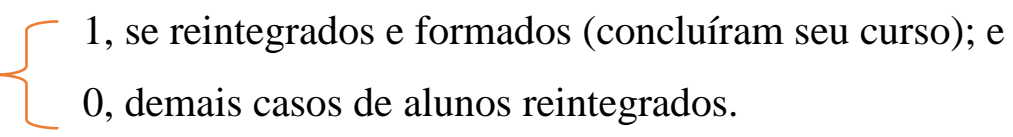

\subsection{Definição das variáveis}

Serão apresentadas as variáveis explicativas usadas nos modelos de regressão para verificar a relação probabilística do perfil do aluno com mais chance de conseguir a reintegração. São muitas as variáveis que podem ser analisadas para explicar as razões de chances de retorno do estudante para a universidade, entre elas estão: gênero, regionais federativas de nascimento, o tipo de curso que estava fazendo, idade, o tempo de permanência na instituição, as formas de ingresso e os motivos do desligamento.

Assim, a equação do método logit binário utilizada para delinear os dados foi:

$$
S_{I}=\left(\frac{P_{i}}{1-P_{i}}\right)=\beta_{0}+\beta_{1} X_{i 1}+\cdots+\beta_{k} X_{i k}+\varepsilon
$$

Em que: 
$S_{i}$ : é a variável dependente do modelo;

$P_{i}$ : é a probabilidade de ser " 1 " ou " 0 ";

$\beta_{0}$ : é o intercepto da equação;

$\beta_{1} X_{i 1}, \ldots \beta_{\mathrm{k}} X_{i k}$ : referem-se às variáveis explicativas da equação;

$\varepsilon$ : erro estocástico.

A partir da função de distribuição logística:

$$
S_{i}=\frac{1}{1+e^{-(\beta)}}=\frac{e^{(\beta)}}{1+e^{(\beta)}}
$$

Onde $\left(1-S_{i}\right)$ representa a probabilidade de o aluno não ser reintegrado. Reescrevendo, tem-se:

$$
\frac{S_{i}}{1-S_{i}}=e^{(\beta)} \text {, em que } \frac{S_{i}}{1-S_{i}} \text { é a razão de chances representada pelo OR }
$$

(OddsRatio) na tabela apresentada nos resultados.

Desse modo, as variáveis explicativas utilizadas nos modelos de regressão podem ser definidas da seguinte forma:

$$
\begin{aligned}
\left(\frac{P_{i}}{1-P_{i}}\right)=\beta_{1} & +\beta_{2} \text { Sexo }+\beta_{3} \text { EscolaPrivada }+\beta_{4} \text { COsemDF }+\beta_{5} \text { Sul }+\beta_{6} \text { Norte } \\
& +\beta_{7} \text { Nordeste }+\beta_{8} F A V+\beta_{9} F A U+\beta_{10} F S+\beta_{11} F A C+\beta_{12} F D \\
& +\beta_{13} F M+\beta_{14} F T+\beta_{15} I B+\beta_{16} I E+\beta_{17} I P O L+\beta_{18} I F+\beta_{19} I G \\
& +\beta_{20} I L+\beta_{21} I P+\beta_{22} F C E+\beta_{23} F U P+\beta_{24} \text { IdadedeIngresso } \\
& +\beta_{25} \text { IdadedeIngressoaoQuadrado }+\beta_{26} \text { TempodePermanência } \\
& +\beta_{27} \text { Estrangeiro }+\beta_{28} \text { Vestibular }+\beta_{29} \text { OutrasFI }+\beta_{30} \text { Cotista }
\end{aligned}
$$

O quadro 2 apresenta as variáveis explicativas dos modelos e os valores atribuídos a elas, conforme abaixo.

Quadro 2 - Variáveis Explicativas

\begin{tabular}{|c|l|}
\hline Variáveis & \multicolumn{1}{c|}{ Valor atribuído } \\
\hline Sexo & $\begin{array}{l}\text { Masculino: 1, se do gênero masculino; } \\
\text { Feminino:0, se do gênero feminino }\end{array}$ \\
\hline Escola & Privada: 1, se estudou em escola privada; 0, caso contrário; \\
\hline
\end{tabular}




\begin{tabular}{|c|c|}
\hline Variáveis & Valor atribuído \\
\hline \multirow{4}{*}{$\begin{array}{l}\text { Cursos dos Institutos } \\
\text { e Faculdades }\end{array}$} & FAV: 1 , se o curso é da FAV; 0, caso contrário; \\
\hline & FAU: 1 , se o curso é da FAU; 0, caso contrário; \\
\hline & FS: 1 , se o curso é da FS; 0, caso contrário; \\
\hline & FAC: 1 , se o curso é da FAC; 0 , caso contrário; \\
\hline \multirow{12}{*}{$\begin{array}{l}\text { Cursos dos Institutos } \\
\text { e Faculdades }\end{array}$} & FD: 1 , se o curso é da FD; 0 , caso contrário; \\
\hline & FM: 1 , se o curso é da FM; 0 , caso contrário; \\
\hline & FT: 1 , se o curso é da FT; 0, caso contrário; \\
\hline & IB: 1 , se o curso é do IB; 0 , caso contrário; \\
\hline & IE: 1 , se o curso é do IE; 0 , caso contrário; \\
\hline & IPOL: 1 , se o curso é do IPOL; 0, caso contrário; \\
\hline & IF: 1 , se o curso é do IF; 0, caso contrário; \\
\hline & IG: 1 , se o curso é do IG; 0 , caso contrário; \\
\hline & IL: 1 , se o curso é do IL; 0 , caso contrário; \\
\hline & IP: 1 , se o curso é do IP; 0 , caso contrário; \\
\hline & FCE: 1 , se o curso é da FCE; 0, caso contrário; \\
\hline & FUP: 1 , se o curso é da FUP; 0, caso contrário; \\
\hline Idade de ingresso & Do aluno no momento do ingresso na universidade. \\
\hline $\begin{array}{l}\text { Idade de ingresso ao } \\
\text { quadrado }\end{array}$ & $\begin{array}{l}\text { É utilizada na dispersão dos dados, captando os ciclos da vida, } \\
\text { eventuais não linearidades. }\end{array}$ \\
\hline $\begin{array}{c}\text { Tempo de } \\
\text { Permanência }\end{array}$ & $\begin{array}{l}\text { É o período em que o discente permaneceu na IES. Para o } \\
\text { cálculo dessa variável, subtraiu-se da data de saída } \\
\text { (desligamento ou formatura) do aluno a sua data de ingresso } \\
\text { na IES. Para os alunos ativos, considerou-se a data de saída, } \\
\text { como referência apenas, } 1^{\circ} \text { de janeiro de } 2015 \text {. Deve-se } \\
\text { observar que, como o intervalo pode incluir o período em que } \\
\text { o aluno esteve afastado antes de ser reintegrado, essa variável } \\
\text { tende a ser menor para os alunos que foram desligados e não } \\
\text { foram reintegrados. }\end{array}$ \\
\hline \multirow{3}{*}{ Forma de ingresso } & $\begin{array}{l}\text { Estrangeiro: } 1 \text {, se a forma de ingresso resulta de acordo ou } \\
\text { convênio destinado a aluno estrangeiro; } 0 \text {, caso contrário; }\end{array}$ \\
\hline & $\begin{array}{l}\text { Vestibular: } 1 \text {, se a forma de ingresso foi pelo Vestibular; } 0 \text {, } \\
\text { caso contrário; }\end{array}$ \\
\hline & $\begin{array}{l}\text { Outras FI: } 1 \text {, se a forma de ingresso for outra não descrita } \\
\text { entre as demais; 0, caso contrário; }\end{array}$ \\
\hline Cotista & $\begin{array}{l}\text { São os discentes que entraram por meio de cotas na } \\
\text { universidade, sejam para negro, índio ou outros. Sendo } 1 \text {, se } \\
\text { entrou pelo meio de Cotas; } 0 \text {, caso contrário; }\end{array}$ \\
\hline \multirow{4}{*}{ Regiões } & $\begin{array}{l}\text { CO sem DF: } 1 \text {, se é nascido no Centro Oeste, mas não no DF; } \\
0, \text { caso contrário }\end{array}$ \\
\hline & Sul: 1 , se é nascido no Sul; 0, caso contrário \\
\hline & Norte: 1 , se é nascido no Norte; 0, caso contrário; \\
\hline & Nordeste: 1 , se é nascido no Nordeste; 0 , caso contrário; \\
\hline
\end{tabular}

Fonte: Dados da pesquisa

Conforme se observa no Quadro 2, tem-se 9 variáveis dummys que podem contribuir com a explicação do desenho dos perfis propostos. 


\section{RESULTADOS OBTIDOS}

\subsection{Estatística Descritiva}

Com o objetivo de conhecer melhor as características gerais do grupo de alunos desligados utilizado neste trabalho, apresentam-se tabelas e gráficos com o intuito de visualizar as principais características dos indivíduos, ou seja, as estatísticas descritivas da população e da subpopulação, dos dois modelos proposto, com base no banco de dados obtido.

A primeira tabela conta com uma população de 18.268 observações que mostram a média, a moda, o desvio padrão (DP), e os valores máximos e mínimos de cada variável. É importante lembrar que as estatísticas categóricas foram transformadas em variáveis dummy.

Tabela 1 - Estatísticas Descritivas das Variáveis que compõem os Reintegrados (R)

\begin{tabular}{c|ccccc}
\hline Variáveis & Média & Moda & $\begin{array}{c}\text { Desvio } \\
\text { Padrão }\end{array}$ & Mínimo & Máximo \\
\hline Reintegrado & 0,270309 & 0 & 0,444131 & 0 & 1 \\
Sexo & 0,613806 & 1 & 0,486889 & 0 & 1 \\
Escola Privada & 0,185735 & 0 & 0,388903 & 0 & 1 \\
UF Não Informada & 0,027972 & 0 & 0,164898 & 0 & 1 \\
DF & 0,540015 & 1 & 0,49841 & 0 & 1 \\
CO sem DF & 0,078826 & 0 & 0,269475 & 0 & 1 \\
Norte & 0,065196 & 0 & 0,246878 & 0 & 1 \\
Nordeste & 0,09273 & 0 & 0,290062 & 0 & 1 \\
Sudeste & 0,16236 & 0 & 0,368791 & 0 & 1 \\
Sul & 0,032899 & 0 & 0,178377 & 0 & 1 \\
FAV & 0,019926 & 0 & 0,139748 & 0 & 1 \\
FAU & 0,006897 & 0 & 0,082765 & 0 & 1 \\
FCI & 0,01998 & 0 & 0,139936 & 0 & 1 \\
FS & 0,025126 & 0 & 0,156512 & 0 & 1 \\
FAC & 0,010839 & 0 & 0,103546 & 0 & 1 \\
FD & 0,012536 & 0 & 0,111261 & 0 & 1 \\
FACE & 0,08649 & 0 & 0,281094 & 0 & 1 \\
FE & 0,015492 & 0 & 0,123501 & 0 & 1 \\
FEF & 0,008485 & 0 & 0,091724 & 0 & 1 \\
FM & 0,010729 & 0 & 0,103027 & 0 & 1 \\
FT & 0,074119 & 0 & 0,261971 & 0 & 1 \\
IDA & 0,060707 & 0 & 0,238799 & 0 & 1 \\
\hline
\end{tabular}




\begin{tabular}{|c|c|c|c|c|c|}
\hline Variáveis & Média & Moda & $\begin{array}{l}\text { Desvio } \\
\text { Padrão }\end{array}$ & Mínimo & Máximo \\
\hline$I B$ & 0,022882 & 0 & 0,14953 & 0 & 1 \\
\hline$I E$ & 0,09908 & 0 & 0,298778 & 0 & 1 \\
\hline$I H$ & 0,06432 & 0 & 0,245329 & 0 & 1 \\
\hline$I P O L$ & 0,019433 & 0 & 0,138045 & 0 & 1 \\
\hline$I C S$ & 0,035581 & 0 & 0,185249 & 0 & 1 \\
\hline$I F$ & 0,037826 & 0 & 0,19078 & 0 & 1 \\
\hline$I G$ & 0,015327 & 0 & 0,122855 & 0 & 1 \\
\hline$I L$ & 0,09804 & 0 & 0,297377 & 0 & 1 \\
\hline$I P$ & 0,007171 & 0 & 0,08438 & 0 & 1 \\
\hline$I Q$ & 0,040508 & 0 & 0,197153 & 0 & 1 \\
\hline IREL & 0,005584 & 0 & 0,074516 & 0 & 1 \\
\hline CET & 0,001752 & 0 & 0,041818 & 0 & 1 \\
\hline$F C E$ & 0,00854 & 0 & 0,092017 & 0 & 1 \\
\hline$F G A$ & 0,020309 & 0 & 0,141058 & 0 & 1 \\
\hline$F U P$ & 0,017189 & 0 & 0,129977 & 0 & 1 \\
\hline Cursos a Distância & 0,155135 & 0 & 0,362043 & 0 & 1 \\
\hline Idade Ingresso & 23,83895 & 18 & 7,453416 & 16 & 66 \\
\hline Idade de Ingresso ao Quadrado & 623,8461 & 324 & 462,2679 & 256 & 4356 \\
\hline Tempo de Permanência & 3,33233 & 1 & 2,411667 & 0 & 16 \\
\hline Estrangeiro & 0,017462 & 0 & 0,130989 & 0 & 1 \\
\hline Outras FI & 0,018448 & 0 & 0,134567 & 0 & 1 \\
\hline Transferências & 0,051839 & 0 & 0,221709 & 0 & 1 \\
\hline Enem & 0,018064 & 0 & 0,133188 & 0 & 1 \\
\hline$P A S$ & 0,114025 & 0 & 0,31785 & 0 & 1 \\
\hline Vestibular & 0,754762 & 1 & 0,43024 & 0 & 1 \\
\hline Cotista & 0,074228 & 0 & 0,262149 & 0 & 1 \\
\hline
\end{tabular}

Fonte: Dados da pesquisa

Assim, observa-se que, no universo de alunos desligados da UnB, apenas $27 \%$ se reintegram. A população possui $61,4 \%$ discentes do sexo masculino e $18,5 \%$ que declaram ter estudado em escola privadas.

Dentre as faculdades e institutos, destacam-se os que cursaram no ensino a distância e nos Institutos de Exatas e Letras, com 15,5\%, 9,9\% e 9,8\% respectivamente.

A idade mais frequente de ingresso dos alunos desligados é de 18 anos. O mais frequente tempo de permanência na instituição é de 1 ano, podendo chegar a 16 anos; porém, é importante ressaltar que pode significar casos de alunos que foram reintegrados mais de uma vez. 
A forma de ingresso mais comum é o vestibular, com 75,5\% de casos, sendo que $7,4 \%$ dos alunos eram cotistas. A região mais representativa é o Distrito Federal, que compreende $54 \%$ dos alunos desligados.

A segunda tabela trata da subpopulação de alunos reintegrados e abrange um total de 4.938 alunos (do universo de 18.268 alunos evadidos no período de 2000 até 2014). Nesta tabela também são apresentados a média, a moda, o desvio padrão (DP), e os valores máximos e mínimos de cada variável.

Tabela 2 - Estatísticas Descritivas das Variáveis que compõem a subpopulação de Reintegrados Formados (RF)

\begin{tabular}{|c|c|c|c|c|c|}
\hline Variáveis & Média & Moda & Desvio Padrão & Mínimo & Máximo \\
\hline Reintegrado Formado & 0,93276 & 1 & 0,250452 & 0 & 1 \\
\hline Sexo & 0,53361 & 1 & 0,498919 & 0 & 1 \\
\hline Escola Privada & 0,17213 & 0 & 0,377536 & 0 & 1 \\
\hline$D F$ & 0,57573 & 1 & 0,49428 & 0 & 1 \\
\hline CO sem DF & 0,07027 & 0 & 0,25563 & 0 & 1 \\
\hline Norte & 0,04090 & 0 & 0,198095 & 0 & 1 \\
\hline Nordeste & 0,09578 & 0 & 0,29433 & 0 & 1 \\
\hline Sudeste & 0,16889 & 0 & 0,374696 & 0 & 1 \\
\hline Sul & 0,02835 & 0 & 0,165992 & 0 & 1 \\
\hline$F A V$ & 0,01397 & 0 & 0,117392 & 0 & 1 \\
\hline FAU & 0,01255 & 0 & 0,111358 & 0 & 1 \\
\hline$F C I$ & 0,02207 & 0 & 0,146938 & 0 & 1 \\
\hline$F S$ & 0,03624 & 0 & 0,186929 & 0 & 1 \\
\hline$F A C$ & 0,01842 & 0 & 0,134509 & 0 & 1 \\
\hline$F D$ & 0,01073 & 0 & 0,103054 & 0 & 1 \\
\hline FACE & 0,08505 & 0 & 0,278991 & 0 & 1 \\
\hline$F E$ & 0,01903 & 0 & 0,136665 & 0 & 1 \\
\hline$F E F$ & 0,00627 & 0 & 0,078992 & 0 & 1 \\
\hline$F M$ & 0,03199 & 0 & 0,176009 & 0 & 1 \\
\hline$F T$ & 0,05893 & 0 & 0,235519 & 0 & 1 \\
\hline$I D A$ & 0,09599 & 0 & 0,294608 & 0 & 1 \\
\hline$I B$ & 0,03402 & 0 & 0,181304 & 0 & 1 \\
\hline$I E$ & 0,06642 & 0 & 0,249046 & 0 & 1 \\
\hline$I H$ & 0,07128 & 0 & 0,257325 & 0 & 1 \\
\hline IPOL & 0,03523 & 0 & 0,184397 & 0 & 1 \\
\hline ICS & 0,04495 & 0 & 0,207232 & 0 & 1 \\
\hline$I F$ & 0,02652 & 0 & 0,160718 & 0 & 1 \\
\hline$I G$ & 0,00951 & 0 & 0,097105 & 0 & 1 \\
\hline$I L$ & 0,12575 & 0 & 0,331612 & 0 & 1 \\
\hline$I P$ & 0,01032 & 0 & 0,101111 & 0 & 1 \\
\hline
\end{tabular}




\begin{tabular}{c|ccccc}
\hline Variáveis & Média & Moda & Desvio Padrão & Mínimo & Máximo \\
\hline IQ & 0,04597 & 0 & 0,209441 & 0 & 1 \\
IREL & 0,00468 & 0 & 0,068096 & 0 & 1 \\
CET & 0,00060 & 0 & 0,024643 & 0 & 1 \\
FCE & 0,00141 & 0 & 0,037628 & 0 & 1 \\
FGA & 0,00789 & 0 & 0,088528 & 0 & 1 \\
FUP & 0,00627 & 0 & 0,078992 & 0 & 1 \\
Cursos a Distância & 0,09781 & 0 & 0,297092 & 0 & 1 \\
Idade de Ingresso & 22,2606 & 18 & 6,059852 & 16 & 62 \\
Idade de Ingresso ao Quadrado & 532,250 & 324 & 362,3969 & 256 & 3844 \\
Tempo de Permanência & 5,95828 & 6 & 1,902175 & 1 & 16 \\
Estrangeiro & 0,00911 & 0 & 0,095036 & 0 & 1 \\
Outras FI & 0,01599 & 0 & 0,125482 & 0 & 1 \\
Transferência & 0,05933 & 0 & 0,236276 & 0 & 1 \\
Enem & 0,00303 & 0 & 0,055037 & 0 & 1 \\
PAS & 0,12819 & 0 & 0,334335 & 0 & 1 \\
Vestibular & 0,73066 & 1 & 0,443662 & 0 & 1 \\
Cotista & 0,06844 & 0 & 0,25254 & 0 & 1 \\
\hline
\end{tabular}

Fonte: Dados da pesquisa

Quando se trata do universo dos alunos reintegrados, tem-se um número bastante expressivo de alunos que concluíram o curso de graduação: um total de 93,3\%. Esse resultado mostra que o processo de reintegração está efetivamente contribuindo para diminuir a evasão, pois demonstra que a quase totalidade dos alunos que retornaram à Universidade entre 2000 e 2014 conseguiram concluir seus cursos.

A subpopulação possui $53,3 \%$ de alunos do sexo masculino e $82,7 \%$ que estudaram em escola pública. Predominam, entre os alunos reintegrados, aqueles que frequentam os cursos do Instituto de Letras $(12,6 \%)$, do ensino a distância $(9,8 \%)$ e do Instituto de Artes (9,6\%).

A idade mais frequente de ingresso dos alunos reintegrados é de 18 anos. Essa idade de ingresso é esperada, uma vez que a maioria dos alunos que terminam o ensino médio já ingressa no ensino superior. O tempo de permanência na instituição é de seis anos, podendo chegar a dezesseis anos. Vale destacar que é esperado do aluno reintegrado ter um tempo de permanência maior que o aluno desligado, precisamente devido ao prazo para conclusão do curso após o retorno à IES.

A forma de ingresso mais comum é o vestibular, com 73,1\% de casos, e 6,8\% de alunos cotistas. O Distrito Federal é a região mais representativa com 57,7\% de alunos reintegrados. 


\subsubsection{Análise Preliminar}

São apresentadas ainda algumas outras relações entre as principais variáveis determinantes do êxito de Reintegrar, assim como de Reintegrar e Formar. Inicialmente, trata-se da relação existente entre a Reintegração, a idade de Ingresso do aluno na UnB e o percentual de alunos desligados por faixa etária, conforme se verifica nos gráficos 1 e 2 .

Gráfico 1 - Taxa de Reintegração (R) por idade de Ingresso do requerente

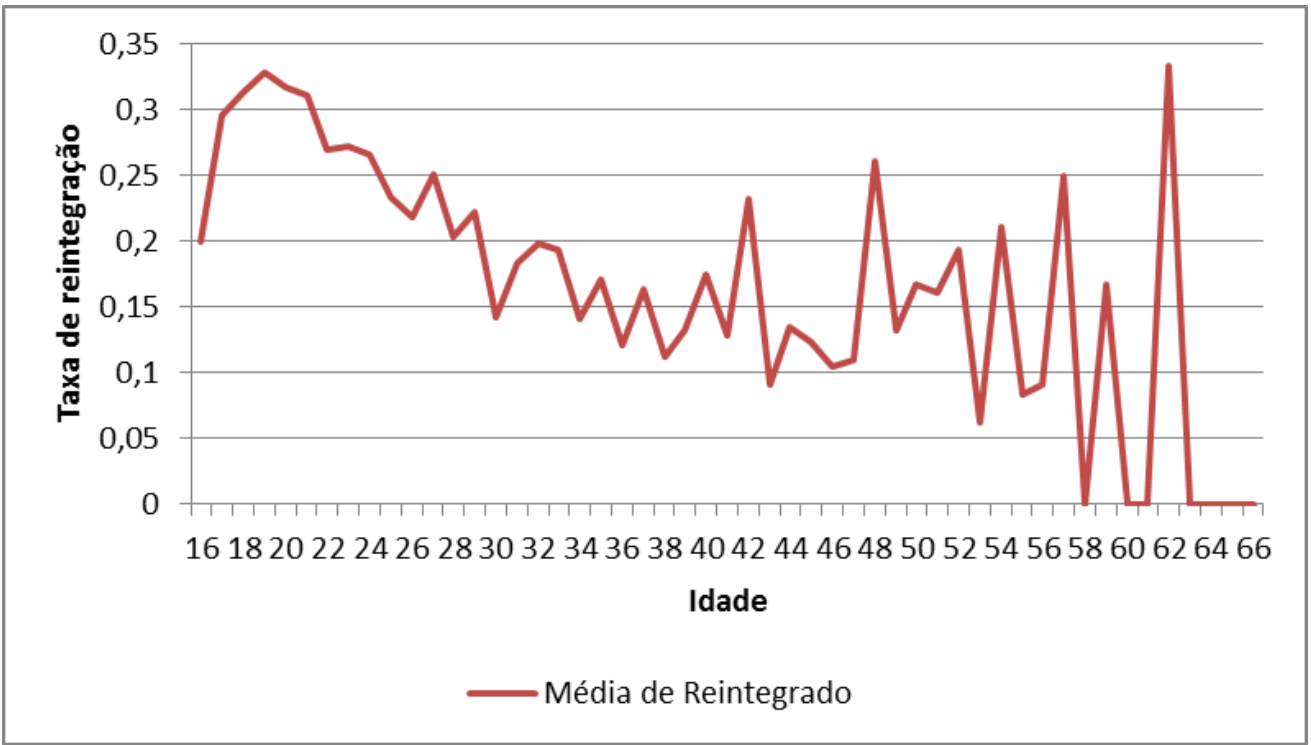

Fonte: Dados da pesquisa

Observe que existe uma maior taxa de reintegração entre os alunos mais jovens. À medida que os anos se passam, a taxa de reintegração diminui apresentando alguns picos em anos específicos como o verificado aos 62 anos. Observe que esse caso se dá em função de proporções menores nessa faixa etária causando volatilidade.

O gráfico 2 a seguir mostra os valores médios de reintegração e de conclusão dos cursos por gênero masculino e feminino, durante o período de 2000 a 2014 na universidade de Brasília. 
Gráfico 2 - Taxas de Reintegração (R) e de Reintegrado Formado (RF) por sexo

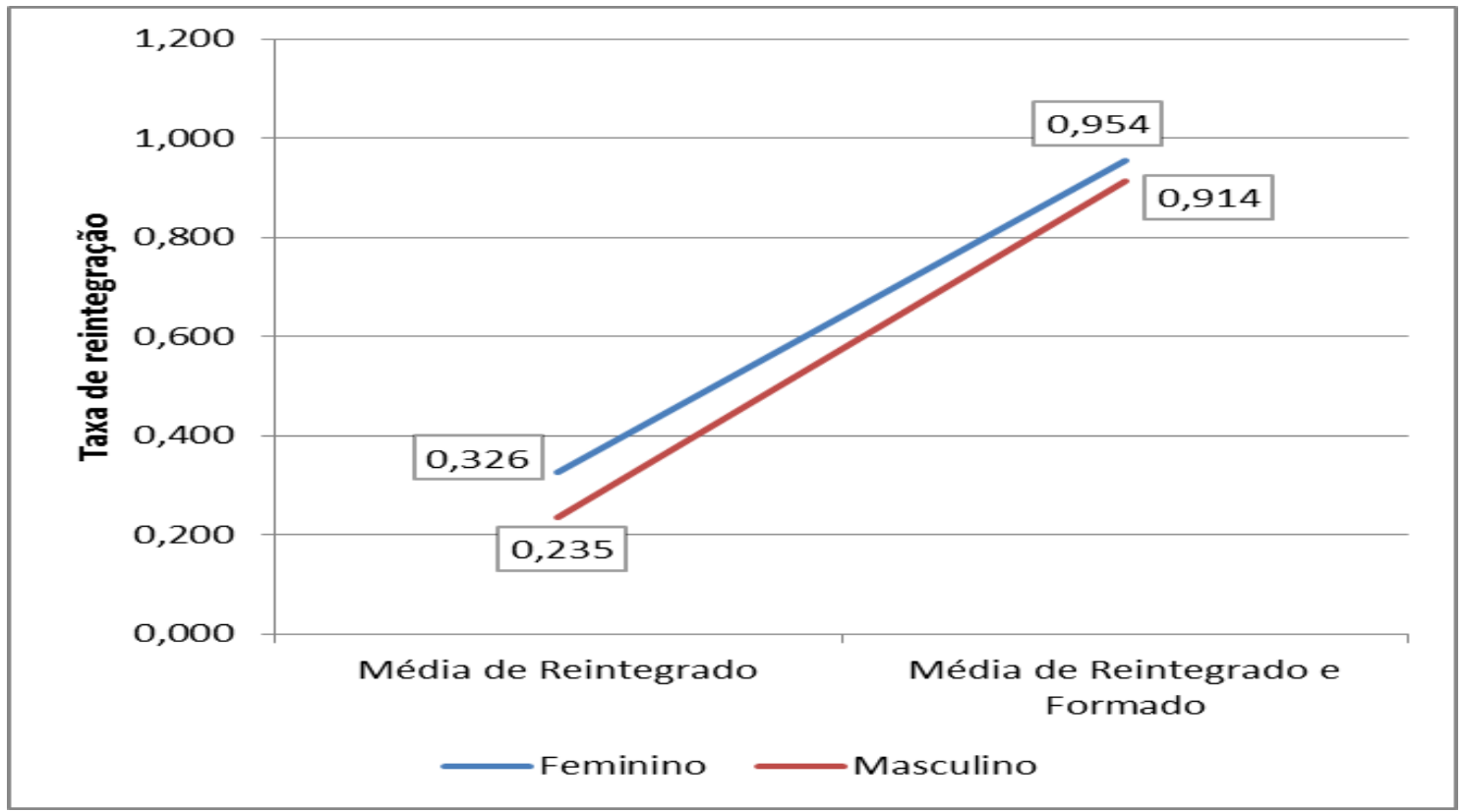

Fonte: Dados da pesquisa

Os dados mostram que, das 32,6\% das discentes que são reintegradas, 95,4\% se formam. Para os alunos do sexo masculino, dos 23,5\% que retornam ao ensino superior, 91,4\% concluem os cursos. Os valores mostram que as mulheres têm uma maior porcentagem de reintegração e de conclusão do que os homens.

O gráfico 3 a seguir apresenta o percentual de mulheres e homens que Reintegram (R) e Reintegram e se Formam (RF).

Gráfico 3 - Percentual que Reintegra (R) e que Reintegra e Forma (RF) por sexo 


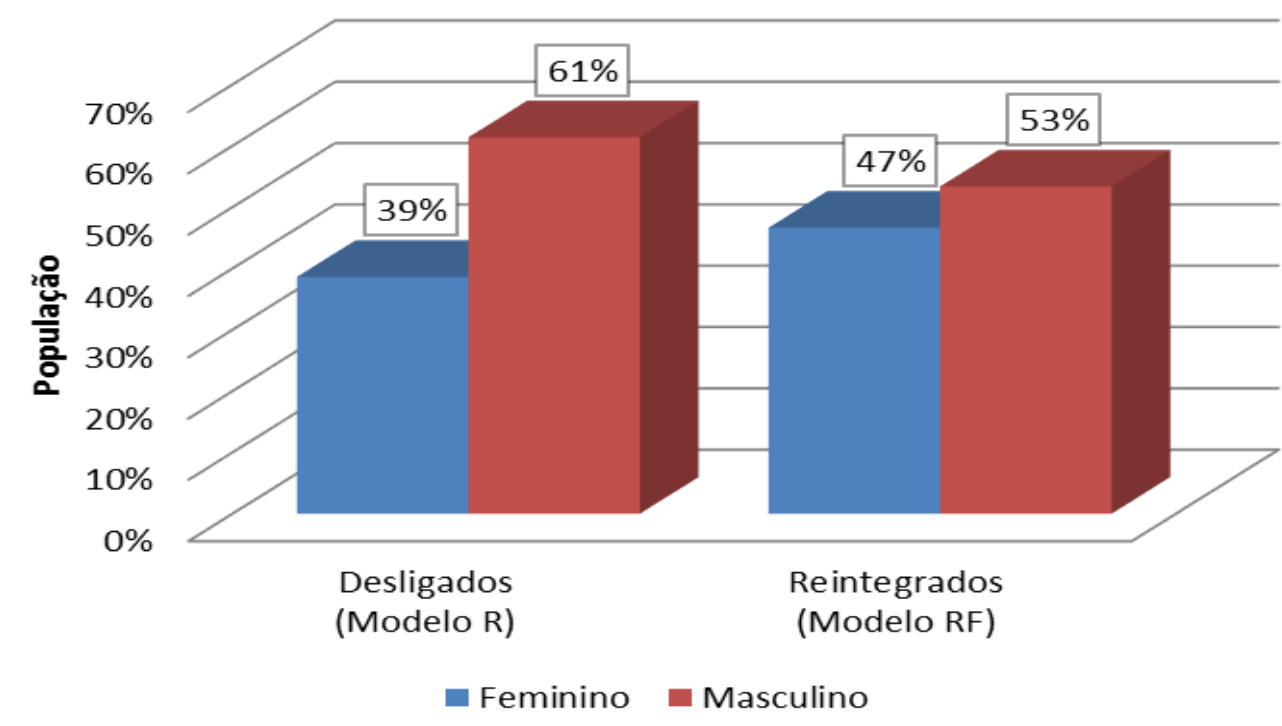

Fonte: Dados da pesquisa

Entre a população de alunos desligados, $61 \%$ são do sexo masculino e $39 \%$ são do sexo feminino. Quando ocorre a reintegração, 53\% de alunos do sexo masculino e $47 \%$ do sexo feminino se formam. Assim, verifica-se que os homens têm uma maior tendência à evasão, conforme apresentado por Braga, Peixoto e Bogutchi (2003), e, também, uma menor proporção de casos de reintegração. De acordo com os autores, o fato de haver mais evasão entre os homens pode ser justificado devido à necessidade de inserção no mercado de trabalho, pois muitos têm a responsabilidade de sustentar a família.

\subsection{Resultado das Regressões}

Foram feitas regressões logísticas para cada um dos dois modelos citados anteriormente, conforme a sua variável dependente.

Buscou-se comparar as variáveis explicativas que possuem os coeficientes estatisticamente significantes no nível de $\alpha \leq 0,01, \leq 0,05, \leq 0,10$ em relação às variáveis dependentes de cada modelo. Os modelos tiveram como referência 29 variáveis explicativas, conforme as variáveis apresentadas na seção anterior deste trabalho.

No total, o modelo Reintegrado apresentou 23 variáveis estatisticamente significantes, enquanto que o outro modelo, Reintegrado Formado, apresentou 16, 
conforme detalhado a seguir. Os resultados obtidos das regressões para os modelos Reintegrados (R) e Reintegrado e Formado (RF) são apresentados na tabela abaixo.

Tabela 3 - Resultados das regressões logit para os dois modelos propostos

\begin{tabular}{|c|c|c|c|c|}
\hline \multirow[t]{2}{*}{ Variáveis } & \multicolumn{2}{|c|}{$\begin{array}{c}\text { Reintegrado } \\
(\boldsymbol{R})\end{array}$} & \multicolumn{2}{|c|}{$\begin{array}{c}\text { Reintegrado Formado } \\
(\mathrm{RF})\end{array}$} \\
\hline & Coeficiente & OR & Coeficiente & OR \\
\hline Constante & $-6,657 * * *$ & 0,001 & $4,867 * * *$ & 129,875 \\
\hline Sexo & $-0,343 * * *$ & 0,709 & $-0,395 * * *$ & 0,674 \\
\hline Escola Privada & $0,560 * * *$ & 1,750 & $1,013 * * *$ & 2,755 \\
\hline FAV & $0,455^{* *}$ & 1,576 & - & - \\
\hline FAU & $-0,275$ & 0,760 & - & - \\
\hline FS & $-0,561 * * *$ & 0,571 & $1,586^{* *}$ & 4,882 \\
\hline FAC & $-0,589 * * *$ & 0,555 & - & - \\
\hline FD & $1,159 * * *$ & 3,188 & $-0,933 * *$ & 0,393 \\
\hline FM & $-2,106 * * *$ & 0,122 & $1,523 * *$ & 4,584 \\
\hline FT & $0,996 * * *$ & 2,708 & $-0,806^{* * *}$ & 0,447 \\
\hline IB & $-0,536 * * *$ & 0,585 & $-0,594 * *$ & 0,552 \\
\hline IE & $0,209^{* *}$ & 1,233 & $-0,887 * * *$ & 0,412 \\
\hline IPOL & $-0,608 * * *$ & 0,545 & - & - \\
\hline $\mathrm{IG}$ & $0,430 * *$ & 1,538 & - & - \\
\hline IF & - & - & $-0,630 * *$ & 0,533 \\
\hline IL & - & - & $0,472 * *$ & 1,603 \\
\hline IP & $0,716 * * *$ & 2,047 & - & - \\
\hline FCE & $1,574 * * *$ & 4,828 & - & - \\
\hline FUP & $0,590 * * *$ & 1,803 & - & - \\
\hline Idade de Ingresso & $-0,007 * *$ & 0,993 & $-0,146^{* *}$ & 0,864 \\
\hline Idade de Ingresso ao Quadrado & - & - & $0,002 * *$ & 1,002 \\
\hline Tempo de Permanência & $0,863 * * *$ & 2,371 & - & - \\
\hline Estrangeiro & $0,822 * * *$ & 2,275 & - & - \\
\hline Vestibular & $0,222 * * *$ & 1,248 & - & - \\
\hline Cotista & $-0,442 * * *$ & 0,643 & - & - \\
\hline Outras Formas de Ingresso & - & - & 1,156 & 3,177 \\
\hline Norte & $0,200 *$ & 1,222 & - & - \\
\hline Nordeste & - & - & $0,361 *$ & 1,434 \\
\hline Centro-Oeste sem DF & - & - & $0,453 *$ & 1,574 \\
\hline Sul & $0,402 * * *$ & 1,495 & - & - \\
\hline $\begin{array}{l}\mathbf{N} \\
\text { Hosmer e Lemeshow } \\
\text { Nagelkerke R Square }\end{array}$ & $\begin{array}{r}18.26 \\
332,697(0 \\
0,584 \\
\end{array}$ & 000) & $\begin{array}{r}4.9 \\
9,526( \\
0,0\end{array}$ & $\begin{array}{l}8 \\
300) \\
5\end{array}$ \\
\hline
\end{tabular}

Fonte: Dados da pesquisa.

Notas: * Estatisticamente significantes a $10 \%$.

** Estatisticamente significantes a 5\%

*** Estatisticamente significantes a $1 \%$. 
Na tabela 3 são apresentados os estimadores, o OddsRatios (que é a razão de chances) representado pela coluna $\mathrm{OR}$, além do tamanho da amostra $(\mathrm{N})$, dos testes de Hosmer e Lemeshow e Nagelkerke R Square.

É importante ressaltar que outras variáveis importantes como alguns Institutos e Faculdades da UnB (FCI, FACE, FE, FEF, IDA, IH, ICS, IQ, IREL, CET, FGA e Cursos a distância), além de algumas formas de ingresso (Transferência, PAS e ENEM), e duas regiões federativas (DF e Sudeste), que estavam disponíveis no banco de dados, não apresentaram significância estatística para nenhum dos dois modelos. Como este trabalho não assumiu uma forma funcional estrita optou-se por não incorporar tais variáveis como variáveis de controle. Assim, foram excluídas por meio do método backward stepwise.

O primeiro modelo apresentado, nominado de "Reintegrados", apresenta a variável dependente zero (não reintegrados) e um (reintegrados). São casos de alunos que conseguiram o reingresso em seus cursos de graduação, após o desligamento da universidade.

O segundo modelo trata da variável dependente "Reintegrados e Formados" para traçar o perfil desses discentes. Destaca-se que, para obter resultados robustos e não inviabilizar os dados neste modelo, foram excluídos os dados de discentes que não foram reintegrados com a variável dependente, considerando 0 (reintegrados não formados) e 1 (reintegrados formados).

Como é possível observar, a variável "sexo" apresentou significância estatística de uma relação direta entre o fato de o requerente a reintegração ser do sexo feminino e obter êxito em sua demanda. Da mesma forma acontece no modelo Reintegrado Formado. As razões de chances (OR) dos modelos indicam que as mulheres têm 29\% de chances superiores a conseguir reintegração, quando comparado aos homens, e 33\% no caso de, conseguindo a reintegração, obter em seguida a conclusão do curso.

Este resultado encontra guarida na farta literatura relacionada à economia da educação e, mais precisamente, nos estudos relacionados ao capital humano, que mostram que as mulheres tendem a apresentar melhores resultados educacionais que os homens, conforme se verifica nos trabalhos de Veloso e Almeida (2001), em que 61,50\% dos alunos evadidos no Campus Universitário de Cuiabá são do sexo masculino e $38,5 \%$ são do sexo feminino. 
Da mesma maneira, Machado e Gonzaga (2007) afirmam que homens têm uma maior demanda para trabalharem mais cedo e ajudar os seus pais no trabalho, ao contrário das mulheres, que cooperam nas atividades domiciliares; portanto, mulheres têm menor probabilidade de defasagem idade-série comparadas aos homens. Em geral, verifica-se que mulheres são mais focadas e disciplinadas em suas tarefas educacionais e, em condições de igualdade na disputa, tendem a alcançar melhores resultados.

Nunca é demais lembrar que o êxito no processo de reintegração não está desconectado com o esforço do requerente. Requerentes que têm melhor retrospecto escolar antes do desligamento e fazem por merecer a confiança de quem julga o processo de reintegração têm maiores chances de obter o que requerem. Assim, não se pode sequer imaginar que tais resultados possam sugerir privilégios relacionados ao gênero.

Outro resultado importante que se verifica no modelo é a variável "Escola Privada". Conforme se verifica em ambos os modelos, as chances dos discentes oriundos deste tipo de escola são muito maiores. Aqueles requerentes oriundos de escolas privadas apresentam $75 \%$ de chances maiores em conseguirem a reintegração quando comparados com os requerentes que não provêm desse tipo de escola, ou mesmo aqueles que não declararam o tipo de escola de origem. Entretanto, o que mais chama atenção é a razão de chances dos requerentes que, uma vez conseguindo a reintegração, conseguem concluir o curso; tal razão de chances é de 176\% maior que aqueles que declararam não originar de escola privada ou mesmo não declararam a escola de origem.

Esse resultado, provavelmente, incorpora aspectos relacionados à renda familiar histórica da família do requerente, assim como o seu background. É sabido que os discentes que têm acesso à rede de ensino particular contam com mais privilégios na sociedade brasileira e conseguem pagar por uma melhor educação e ambiente de estudo. Tais consequências tendem a se perpetuar durante toda a trajetória escolar e laboral dos indivíduos, conforme apresenta Menezes Filho (2006), que afirma que os alunos de escolas privadas têm maiores desempenhos comparados aos alunos de escolas públicas, além de que as diferenças entre as escolas são de $10 \%$ a $30 \%$ nas notas obtidas pelos discentes de rede pública.

Em outro estudo, Guimarães e Arraes (2010) mostra que as maiores chances de sucesso de aprovação no vestibular da Universidade Federal do Ceará são maiores com 
os discentes que cursaram o ensino médio em escolas da rede particular. Silva Junior e Amorim (2013) constatou também que em Belo Horizonte há uma correlação entre os alunos que obtiveram bons resultados nas notas no vestibular das escolas particulares e a percepção do mercado em relação ao desempenho das universidades públicas.

O background familiar também é outro aspecto relevante na formação dos indivíduos e possivelmente este resultado detecta tais efeitos. É sabido que indivíduos que têm um melhor ambiente familiar, geralmente entendido ou medido como a escolaridade dos pais, tem melhores resultados educacionais e maiores êxitos em sua trajetória laboral, conforme verificou em Silva Júnior e Sampaio (2015).

O modelo também apresenta resultados para as Faculdades e Institutos que compõem a Universidade de Brasília. É importante lembrar que o processo de reintegração neste período estudado se dava por meio do pedido de reintegração do aluno, que era analisado pela Comissão. Assim, não seria correto afirmar que os diferenciais de probabilidades de êxito na reintegração e em seguida na conclusão do curso se devam pelo fato de critérios de maior ou menor rigor de exigências levadas aos requerentes por essas faculdades e institutos. Provavelmente, tais diferenciais se explicam pelo maior denodo dos requerentes, assim como, provavelmente, as expectativas que cada curso pode trazer sobre remuneração e bem-estar futuro no mercado de trabalho.

Outro aspecto também relevante pode ser as razões que levaram o requerente, na ocasião como aluno da UnB, a evadir. Conforme se verifica no item 2.4, existem pelo menos 10 razões que poderiam levar esse aluno a evadir.

A tabela 3 mostra que os alunos da "FAV" Faculdade de Agronomia e Medicina Veterinária apresentam uma razão de chances na ordem de 1,576 vezes maior de reintegrar que a média dos demais discentes que evadem. Outro aspecto que chama atenção é que uma vez que esse aluno é reintegrado não se pode afirmar que tenha, em média, mais chances, em relação aos demais que reintegram, de conseguir se formar, uma vez que o parâmetro estimado para o modelo RF não apresentou significância estatística.

A variável da "Faculdade de Arquitetura e Urbanismo" não apresentou significância estatística para nenhum dos dois modelos propostos (Reintegrados $-\mathrm{R}$ e Reintegrados Formados -RF). 
A Faculdade de Saúde "FS" apresenta resultados curiosos das regressões logit. Os resultados apresentam evidências de que os alunos que evadem dessa faculdade têm uma chance menor de reintegrar. Conforme se verifica no Modelo (R) da Tabela 1, essas chances são na ordem de 0,571 quando comparado com as demais faculdades analisadas. Entretanto, uma vez que esses discentes reintegram, eles apresentam a maior OR dentre as Faculdades analisadas. A razão de chances nesse caso é na ordem de 4,882 , ou seja, esse aluno tem cerca de 5 vezes mais chances de se formar depois que é reintegrado, quando comparado com os alunos das demais Faculdades e Institutos analisados.

Essa questão talvez tenha relação com o fato de que a maioria dos discentes que evadem dessa Faculdade o faz por força maior de convicção de sua decisão e, dessa maneira, tem menor intenção de requerer e tentar seu retorno. Contudo, a parte que evade por motivos alheios ao seu interesse, uma vez que consegue reverter o processo, encontra razões, seja por motivos vocacionais ou pela atratividade do mercado de trabalho, ou ambas, a retornarem com afinco as suas atividades e eleva as chances de reintegrar e concluir seu curso.

Os estudantes dos cursos da Faculdade de Comunicação "FAC" possuem 45\% menos chance de serem reintegrados. Em comparação com o modelo de Reintegrados Formados, não houve significância estatística. Com isso, pode-se pressupor que por razões diversas, falta de expectativa salarial e de identidade com o curso, os discentes que evadem talvez tenham menos interesse em retornar para a universidade.

Por outro lado, os alunos da Faculdade de Direito "FD" têm 3,188 razões de chances de ser reintegrado e 0,393 menores chances de concluir o curso, comparados aos outros institutos e faculdades. Pode-se esclarecer, nesse caso, que a maioria dos discentes desse curso pode estar mais interessada em fazê-lo por conta dos concursos públicos. Assim, quando o aluno busca se reintegrar, ele investe no seu capital humano até passar em um concurso. Outra possível explicação é que não basta apenas concluir o curso de graduação para exercer a profissão, é preciso investir mais tempo, esforço e dinheiro para passar no Exame da Ordem dos Advogados do Brasil (OAB), e isso pode fazer com que o aluno desista do curso.

Quando se trata da Faculdade de Medicina "FM", tem-se 0,122 razão de chance de não reintegrar. Ao analisar os dados dos que são reintegrados, apresenta-se 4,584 razões de chance de concluir. Esse resultado pode estar relacionado com o fato de que, 
quando o aluno ingressa no curso de medicina, ele cria uma expectativa diferente da realidade, uma vez que o curso pode exigir além do esperado, tanto psicologicamente como intelectualmente. Quanto aos alunos que concluem o curso, pode estar relacionado com os que já demostraram uma maior dedicação e esforço por terem conseguido ingresso em curso tão concorrido.

Semelhante aos discentes do Instituto de Exatas "IE", que apresentam 23\% de chance de reintegrar e 59\% menos chance de formar após ser reintegrado, os alunos evadidos da Faculdade de Tecnologia "FT" têm 171\% chance de reintegrar e 55\% menos chance de concluir o curso em relação aos que evadem das demais faculdades e Institutos. Destaca-se que os cursos de Exatas e Engenharias têm certo grau de dificuldade que exige muita dedicação e estudo, principalmente em disciplinas de cálculo.

\footnotetext{
Diversas pesquisas para determinação do perfil de alunos ingressantes nos cursos da área de Exatas e Engenharia têm demonstrado que muitos estudantes apresentam falhas de aprendizagem em conteúdos de ensino fundamental e médio que dificultam o acompanhamento das disciplinas que compõem os currículos básicos dos primeiros anos de sua formação. Essas deficiências, como falta de domínio de conteúdos específicos, e dificuldades para interpretar questões, relacionar conceitos já estudados a situações novas, formular e resolver problemas, quando não superadas, vão se multiplicando ao longo do curso, gerando outras deficiências que comprometem a qualidade do aluno formado (LEHMANN, 2006, p.2).
}

No Instituto de Biologia "IB", os discentes têm 0,585 razões de chance de não se reintegrar e 0,552 menores razões de chance de concluir. Isso pode significar que são alunos que descobrem que não se identificam com o curso e acabam não retornando ou acham que a área tem uma baixa expectativa salarial. Conforme Bueno (1993, p.11), as "chances limitadas de emprego, com falta de prestígio, de condições de trabalho, de sucesso financeiro, a realização profissional passa a ser apenas uma fantasia na cabeça dos estudantes de cursos que levam [..] estas características".

Os Institutos e Faculdades que tiveram impacto estatístico significativo apenas no modelo R - Reintegrados foram: Instituto de Ciências Políticas "IPOL”, Instituto de Geociências "IG", Instituto de Psicologia "IP", Faculdade da Ceilândia "FCE" e Faculdade de Planaltina "FUP". O resultado do "IPOL" mostra 46\% menos chance de reintegração. Supõe-se que são casos de discentes que nem sequer solicitam a reintegração e ao evadir do curso vão direto para o mercado de trabalho ou entram 
novamente no processo seletivo de ingresso na instituição (novo vestibular) para cursar outra graduação.

Os demais resultados, "IG", "IP" "FCE" e "FUP", representam respectivamente um aumento de 54\%, 105\%, 383\% e $80 \%$ de chance de reintegrarem em seus cursos de graduação. Presume-se que os discentes dos Institutos de Geociências e Psicologia têm uma maior identificação com o curso e que por razões diversas inerentes às pessoas passam por algum momento de deslize acadêmico no qual acabam se desligando do curso.

Para os resultados das Faculdades da "Ceilândia" e de "Planaltina", conforme visto anteriormente na literatura, esses campi foram criados para estimular o desenvolvimento regional e atender a demanda da sociedade e com isso pressupõe-se que, por se tratar de um público de alunos que tem menos oportunidade de acesso à UnB, talvez por esse motivo os alunos deem mais valor à sua formação quando reintegrados.

Os dois últimos Institutos a serem analisados tiveram impacto significativo estatístico apenas para o modelo de Reintegrados Formados (RF) e foram os Instituto de Física "IF" e de Letras "IL". Destaca-se que os discentes do IF têm 0,533 razões menores de chance de concluir o curso. Como já citado nos resultados do IE, os cursos que envolvem a área de exatas exigem mais do aluno. Por outro lado, o aluno do IL, por serem cursos que exigem menos, tem $60 \%$ mais chance de concluir o curso.

A variável "idade de ingresso" foi estatisticamente significante nos dois modelos e a variável "idade de ingresso ao quadrado" foi significante apenas no modelo RF. No entanto, a variável "idade de ingresso" mostrou uma relação inversa em ambos os modelos, com respectivamente $1 \%$ e $14 \%$, ou seja, quanto mais velho o aluno ao entrar na universidade, menor seria a chance de ser reintegrado e, uma vez que retorne à instituição, menor também a chance de concluir o curso.

Constata-se que a "idade de ingresso ao quadrado" é significativa na razão direta, mas apesar de ser significante, a contribuição dela para a probabilidade de concluir o curso (em $0,2 \%$ ) é muito pequena, quase nula, para explicar a variável dependente, uma vez que o Exp (B) está muito próximo de 1.

A variável "tempo de permanência" é estatisticamente significante para o modelo R. Conforme se verifica, para cada ano desde a data de ingresso do aluno na universidade antes de seu desligamento, as chances de ele ser reintegrado aumentam em 
137\%. Pode-se pressupor que a probabilidade de o aluno ser reintegrado é maior por faltarem poucos créditos ou somente o trabalho final de curso, o que influencia na avaliação da pessoa que analisa o processo.

Vale lembrar que, conforme a regra anterior, a solicitação de reintegração podia ser feita até dois anos depois do seu desligamento. Essa regra entrou em vigor a partir de 2009. Portanto, antes disso, o aluno não tinha um prazo máximo, depois de desligado, para solicitar a reintegração. Assim, principalmente para os alunos reintegrados, o tempo de permanência não significa necessariamente tempo ativo na universidade. Além disso, para os casos com menor tempo de permanência, imagina-se que grande parte dos desligamentos se deva à falta de identificação com o curso.

No que se refere à "Forma de Ingresso" por meio da qual o discente entra na IES, apresentam-se positivamente significantes no modelo $\mathrm{R}$ as variáveis "Estrangeiro" e "Vestibular". Nesses casos, as probabilidades de reingresso foram respectivamente $127 \%$ e $25 \%$. Para o modelo de Reintegrados Formados (RF), os discentes que ingressaram por "Outras formas de ingresso" têm 3,177 vezes mais chances de concluir o curso de graduação.

Além disso, observa-se nos resultados que ser "cotista" é uma variável estatisticamente significante, que contribui inversamente para a probabilidade de reintegração. O aluno cotista possui 36\% menos chance de ser reintegrado. Pode-se esclarecer, nesse caso, que o aluno cotista pode ter mais chances de retornar para a universidade por outras formas de ingresso (como outro vestibular) do que conseguir a reintegração. E tendo em vista a política de diversidades da universidade, ele acredita ter mais acesso à UnB.

Por último, as regiões federativas que se mostram como significativas estatisticamente, no modelo Reintegrados (R), são as regiões do Norte e Sul do Brasil, à qual corresponde o efeito positivo da variável, aumentando em $22 \%$ e $49 \%$ as chances de ser reintegrado.

Wing e Silva Júnior (2010) analisam que os estudantes que vêm de regiões mais distantes para ingressar na universidade são pessoas mais motivadas e que conquistam resultados melhores. Deduz-se que essa mesma motivação pode explicar uma maior tendência dos alunos dessas regiões (Norte e Sul) a busca reingressar na universidade por meio da reintegração. 
As regiões do Nordeste e do Centro-Oeste (exceto o DF) apresentaram significância para o modelo RF, sendo $49 \%$ e $57 \%$, respectivamente, maiores as chances de o discente concluir o curso. No caso do Centro-Oeste, especula-se que os alunos dessa região têm uma tendência maior de concluir o curso, após serem reintegrados, seja pelo fato de estarem mais próximos do $\mathrm{DF}$, ou acostumados com a região Centro-Oeste.

Quanto à região Nordeste, pode-se prever neste caso que, devido às várias dificuldades relacionadas ao desemprego nessa região, é mais comum dar valor na obtenção de um curso de nível superior para uma melhor inserção no mercado de trabalho.

O Sul é onde as crianças possuem maiores oportunidades de instrução, ao contrário das regiões Norte/Nordeste e Centro-Oeste. Por outro lado, nas áreas metropolitanas, a probabilidade da criança acumular defasagem idadesérie é maior que nas não metropolitanas. Apesar da oferta educacional possivelmente ser melhor nestas localidades, podem existir outros fatores, como os associados à atratividade do mercado de trabalho, incentivando a saída da escola e a não dedicação aos estudos (MACHADO; GONZAGA, 2007).

Assim, dado o primeiro modelo (Reintegrados - R), verifica-se que o discente que possui maior probabilidade de ser reintegrado, ou seja, com maior coeficiente do modelo rodado, tem as seguintes características:

* É do sexo feminino;

* Estudou em escola privada;

* Cursa na Faculdade UnB de Ceilândia;

* É mais jovem

* Teve o maior tempo de permanência na UnB;

* Entrou por acordo cultural (estrangeiro); e,

* Não é cotista.

Assumindo as características acima que corroboram para a maior chance de traçar o perfil e ao colocar na equação os resultados obtidos de algumas variáveis (considerando, ainda, 16 anos como o maior tempo de permanência desde a data de ingresso do aluno na universidade), a probabilidade de um aluno ser reintegrado com este perfil é de 8,421 vezes maior.

Constata-se que, os dados apresentados com maior coeficiente rodado, no segundo modelo (Reintegrados Formados - RF), as características do aluno que tem a 
maior probabilidade de ser reintegrado e se formar no curso de graduação são as seguintes:

* É do sexo feminino;

* Estudou em escola privada;

* Cursa na Faculdade da Saúde;

* É mais jovem;

* Entrou por uma das formas de ingresso descrita "Outras Formas de Ingresso"; e,

* Nasceu no Centro-Oeste (exceto no DF).

Dado o perfil descrito acima, os resultados obtidos de algumas variáveis que corroboram para a maior chance de traçar o perfil e considerando a menor idade de ingresso como 16 anos (registrada no banco de dados), tem-se que esse aluno teria uma probabilidade 6,739 vezes maior de ser reintegrado e se formar.

Portanto, essa seção finaliza com a apresentação dos dois perfis proposto nos objetivos do trabalho, sendo consideradas as características de maior impacto para estimar o valor do perfil e com dados no qual poderão contribuir para outras pessoas interessadas no assunto para desenvolverem suas pesquisas e temas futuros sobre o assunto. 


\section{CONSIDERAÇÕES FINAIS}

A evasão tem afligido muitas Instituições de Ensino Superior (IES), no mundo

contemporâneo. É cada vez mais imprescindível compreender as causas e fatores para mudar esta situação, que tem sido progressivamente mais frequente no ensino superior, tanto em instituições públicas como particulares.

Independentemente da forma como o aluno ingressa na UnB, o número elevado da taxa de desligamentos é bastante preocupante e requer mudanças de ações que previnam e combatam a evasão. Por esse motivo, o processo de reintegração é um mecanismo importante, que contribui tanto para a redução dos índices de evasão quanto para a formação do capital humano.

Destaca-se que é necessária a criação de uma equipe de integração, para que se possa compreender, estudar e combater a evasão. Todos os problemas da instituição passam pela gestão universitária e nessa gestão cabe buscar medidas que saem da zona de conforto de muitos envolvidos, como professores, gestores e até mesmo os alunos. Todos precisam ser capacitados para garantir o sucesso e o aprendizado dos alunos, pois "Não se pode ensinar o aluno a ser um profissional e um cidadão comprometido quando uma IES demonstra amadorismo em seus processos [...]" (LOBO 2012, p.21).

Constatou-se que a grande parte das justificativas que levaram o estudante a desligar está relacionada com a falta de intervenção acadêmica. Com o devido acompanhamento psicopedagógico adequado aos estudantes, a partir do momento em que o aluno entra em condição, muitas das evasões poderiam ser evitadas.

Através dos resultados obtidos no presente trabalho, observou-se que uma série de variáveis está relacionada com o retorno do aluno aos cursos de graduação e com isso foi possível traçar perfis cujas características relacionam-se com maiores chances de o aluno se reintegrar e formar na Universidade de Brasília.

Os resultados apontam que o indivíduo típico cujas características estão relacionadas com uma maior probabilidade de ser reintegrado é do sexo feminino, estudou em escola privada, cursa na Ceilândia, é mais jovem, teve o maior tempo de permanência na UnB desde a data do seu ingresso, entrou por acordo cultural (estrangeiro) e não é um aluno cotista. Essas características estão relacionadas a 8,421 vezes mais chance de ser reintegrado. 
Para o discente se formar, após ser reintegrado, as características do perfil do indivíduo típico apontam para uma relação com uma probabilidade 6,739 vezes maior. Essas características são de um aluno do sexo feminino, que estudou em escola privada, cursa na Faculdade da Saúde, é mais jovem, teve o maior tempo de permanência na UnB desde a data do seu ingresso, entrou por outras formas de ingresso e nasceu na região do Centro Oeste (ressalvado o DF).

Considerando que o êxito acadêmico de um aluno desligado decorre de conseguir ser reintegrado à universidade e concluir a sua graduação, observou-se que algumas características nos dois perfis coincidiram na sua relação com esse êxito. Ambos os perfis indicam, assim, que alunos do sexo feminino, que estudaram em escola privada, são mais jovens e permaneceram mais tempo na universidade compartilham aspectos relacionados a uma maior probabilidade de sucesso nos estudos acadêmicos.

Cabe sempre lembrar, a propósito, que - como apontado anteriormente - alunos que têm melhor retrospecto escolar antes do desligamento e fazem por merecer a confiança de quem julga o processo de reintegração têm maiores chances de obter o que requerem. Não se deve, assim, desconsiderar a relevância do esforço do requerente em seu êxito no processo de reintegração e não se deve supor que tais resultados possam sugerir privilégios.

Com base em todos os dados fornecidos e apresentados, deseja-se, então, que seja possível subsidiar informações e contribuir para que tanto a Universidade de Brasília como outras instituições de ensino, públicas ou privadas, vejam as necessidades de mudanças. É necessária a implementação de futuras políticas públicas voltadas a esses alunos em situação de risco acadêmico. As instituições precisam criar mecanismos eficientes para reduzir o número de evasão nos cursos de graduação, melhorando o aproveitamento acadêmico dos estudantes e a qualidade do ensino superior.

É importante frisar que a UnB tem grande representatividade social no Distrito Federal, uma vez que é uma das universidades públicas que oferece várias oportunidades de ingresso e tem uma diversidade de cursos de graduação conforme a demanda social. Com isso, as pessoas que residem nas regiões administrativas e ao redor de Brasília têm a oportunidade de entrar no ensino superior público de qualidade.

É recomendável que o governo concentre esforços em estudos e pesquisas para combater a evasão. As universidades carecem de preparo intelectual, além do apoio financeiro voltado ao tema em questão, para mudar essa realidade assustadora dos altos 
índices de evasão. A educação transforma um país e, para isso, nada melhor que universidades capazes de desempenhar com excelência o seu papel de educar e formar pessoas e profissionais.

Uma das principais limitações deste estudo foi o fato de não ser possível encontrar temas relacionados a como se dá o processo de reintegração de um aluno à instituição de ensino. Foi possível abordar os estudos que tratam da evasão, mas poucos voltados para a área da reintegração. Ao longo desta pesquisa foi possível encontrar apenas duas pesquisas americanas que trataram sobre a reintegração e desligamento em instituições de ensino superior fora do Brasil. Essas duas pesquisas foram fundamentais para contribuir com o referencial teórico deste trabalho, e com isso se faz necessário recomendar a continuidade em mais pesquisas que tratem especificamente do tema da reintegração. 


\section{REFERÊNCIAS BIBLIOGRÁFICAS}

BRAGA, Mauro Mendes; PEIXOTO, Maria do Carmo L.; BOGUTCHI, Tânia. F. A evasão no ensino superior brasileiro: o caso da UFMG. Avaliação-Revista da Rede de Avaliação Institucional da Educação Superior. Campinas: vol8, n.1, mar. 2003.

BRASIL. Ministério da Educação, Secretaria da Educação Superior - SESu. Diplomação, retenção e evasão nos cursos de graduação em Instituições de Ensino Superior Públicas. Relatório da Comissão Especial de Estudos sobre Evasão nas Universidades Públicas Brasileiras, ANDIFES/ABRUEM/SESu/MEC, 134p. out. 1997.

Lei n. 3.998, de 15 de dezembro 1961. Autoriza o Poder Executivo a instituir a Fundação Universidade de Brasília, e dá outras providências. Disponível em:< http://www.planalto.gov.br/ccivil_03/leis/1950-1969/L3998.htm>. Acesso em: 25 jan 2016.

BUENO, José Lino. A evasão de alunos. Paidéia, Ribeirão Preto, n. 5, p. 9-16, ago. 1993.

CORRAR, Luiz J.; PAULO, Edilson; FILHO, José M. Dias. Análise multivariada: para os cursos de administração, ciências contábeis e economia. São Paulo: Atlas, 2009.

FÁVERO, Maria de Lourdes de Albuquerque. A universidade no Brasil: das origens à reforma universitária de 1968. Curitiba: Educar Editora UFPR, n. 28, p. 17-36, 2006.

FERREIRA, Marco Aurélio Marques; CELSO, Alex Sandro dos Santos; NETO, João Estevão Barbosa. Aplicação do modelo logit binominal na análise do risco de crédito em uma instituição bancária. Revista de Negócios, Blumenau, v.17, n.1, p.41-59 jan/março 2012.

FUNDAÇÃO UNIVERSIDADE DE BRASÍlLIA (FUB). Plano de expansão da Universidade de Brasília: Campus UnB - Planaltina: Campus UnB Ceilândia/Taguatinga: Campus UnB - Gama. Brasília: FUB, abr, 2005.

Plano de Reestruturação e Expansão da Universidade de Brasília, 20082012. Brasília: Editora UnB, 2008.

GUIMARÃES, D. B.; ARRAES, R. A. Status Sócio-Econômico, Background Familiar, Formação Educacional e as Chances de Sucesso dos Candidatos ao 
Vestibular da UFC. Revista Contemporânea de Economia e Gestão, v.8, n. 2, p. 81-94, jul./dez. 2010.

HAIR Jr. J. F.; ANDERSON, R.E.; TATHAM, R.L.; BLACK, W. C. Análise multivariada de dados. 5. ed., Porto Alegre: Bookman, 2005.

LEHMANN, M.S.; LEHMANN R.B; Estudo da correlação entre o desempenho no vestibular e em disciplinas do $1^{\circ}$ período dos cursos de engenharia da universidade Severino Sombra. In: Congresso Brasileiro de Ensino de Engenharia, 2006, Passo Fundo. Anais. Porto Alegre: ABENGE, 2006.

LOBO, Maria Beatriz de Carvalho Melo. Panorama da Evasão no Ensino Superior Brasileiro: Aspectos Gerais das Causas e Soluções. Associação Brasileira de Mantenedoras de Ensino Superior. Cadernos ABMES, n. 25, p. 09-58, Brasília, 2012.

MACHADO, D. C.; GONZAGA, G. O impacto dos fatores familiares sobre a defasagem idade-série de crianças no Brasil. Revista Brasileira Economia. Vol.61, n.4, pp. 449-476, 2007.

MENEZES FILHO, N. Os Determinantes do Desempenho Escolar no Brasil. São Paulo: Instituto Futuro Brasil, IBMEC, FEA/USP, 2006.

OLIVEIRA, João Ferreira de; DOURADO, Luís; MENDONÇA, Erasto Fortes Mendonça. UnB: Da universidade idealizada à "universidade modernizada". In: MOROSINI, Marília Costa (Org.). A universidade no Brasil: concepções e modelos. Brasília: Inep, 2006, p. 113-131.

OSBORNE, Jennifer Ames. Gaining insight on the experiences of reinstated undergraduate students. 2013. 158p. Dissertation (Doctor of Education in Educational Leadership) - California State University, California - USA, may. 2013.

REYNOLDS, Jaime L. A case study analysis of reinstated students' experiences in The learning to establish academic priorities (leap) Reinstatement intervention program. 2013. 285p. Dissertation (Doctor of Philosophy) - Kent State University College of Education, Health, and Human Services, Kent - USA, may. 2013.

SANTOS, Jaqueline Silva dos; SILVA JÚNIOR, Luiz Honorato da. Determinantes socioeconômicos do consumo e disposição a pagar por alimentos orgânicos no agreste de Pernambuco. Reflexões Econômicas, v.1, n.1, p. 49-84. abr./set. 2015 
SEVERINO, A. J. Expansão do Ensino Superior: Contextos, Desafios, Possibilidades. VI Fórum dos Pró-Reitores de Graduação da Região Sudeste (FORGRAD), Sorocaba - SP, Julho 2009. 14.

SILVA FILHO, Roberto L. Lobo; MOTEJUNAS, Paulo Roberto; HIPÓLITO, Oscar; LOBO, Maria Beatriz de C. M. A evasão no ensino superior brasileiro. Cadernos de Pesquisa, v. 37, n. 132, p. 641 - 659, set./dez. 2007.

SILVA JÚNIOR, Luiz Honorato da. Pobreza, qualidade da escola e background familiar influenciando a educação no Brasil: uma análise à luz da teoria do capital humano. 171f. 2009. Tese de doutorado, PIMES-UFPE, 2009.

SILVA JÚNIOR, Luiz Honorato da; AMORIM, Jefferson Gonçalves de. Fatores Socioeconômicos que influenciam o desempenho educacional: Uma análise dos alunos concluintes da autarquia educacional de belo jardim no agreste de Pernambuco. Revista Economia e Desenvolvimento, Recife, v. 12, n. 2, 2013.

SILVA JÚNIOR, Luiz Honorato da; SAMPAIO, Yony. Pobreza e Demanda por Educação no Brasil: uma análise à luz da teoria do capital humano. Ensaios FEE, Porto Alegre, v. 34, p. 123-148, 2013.

SILVA JUNIOR, Luiz Honorato da; SAMPAIO, Yony. Qualidade da Escola e Background Familiar na Formação de Capital Humano no Brasil. Revista PPP Planejamento e Políticas Públicas, n. 45, jul/dez. 2015.

Universidade de Brasília (UnB). Comissão Própria de Avaliação Institucional - CPA. Relatório de Auto avaliação Institucional: Período do Relatório - 2013. Brasília, mar. 2014a.

Conselho de Ensino, Pesquisa e Extensão - CEPE. Resolução n. 41, de 10 de maio de 2004. Dispõe sobre a orientação acadêmica de estudante de graduação e condições para desligamento. Brasília: 2004.

Criação.

Disponível

em:

$\overline{<\mathrm{http}: / / w w w . u n b . b r / s o b r e / p r i n c i p a i s \_c a p i t u l o s / c r i a c a o>. ~ A c e s s o ~ e m: ~} 25$ jan. 2016.

Decanato de Ensino de Graduação - DEG. Guia do Coordenador de Curso de Graduação. Brasília. 2012a. 
Decanato de Ensino de Graduação - DEG. Instrução Normativa da Câmara

de Ensino de Graduação n. 001 de 04 de setembro de 2012. Estabelece procedimentos para tratar de processos de discente em risco de desligamento reintegração e orientação acadêmica. Brasília. 2012b.

Decanato de Ensino de Graduação - DEG. Instrução Normativa da Câmara de Ensino de Graduação n. 001 de 02 de dezembro de 2014. Estabelece procedimentos para tratar de processos de reintegração de discente desligado. Brasília. $2014 b$

Decanato de Planejamento e Orçamento - DPO. Anuário Estatístico da UnB 2015 (2010-2014). Versão parcial. Brasília, jul. 2015.

Decanato de Planejamento e Orçamento - DPO. Anuário Estatístico 2011 (2006-2010). Brasília: FUB, out. 2011 a.

Decanato de Planejamento e Orçamento - DPO. Anuário Estatístico 2013 (2008-2012). Brasília, out. 2013.

. Decanato de Planejamento e Orçamento - DPO. Anuário Estatístico 2014 (2009-2013). Brasília, out. 2014c.

Decanato de Planejamento e Orçamento - DPO. Plano de Desenvolvimento Institucional 2014 - 2017. Brasília, jul. 2014d.

Estatuto e Regimento Geral. $8^{\text {a }}$ edição. Brasília: Editora UnB, 2011 b.

VELOSO, Tereza Cristina. M. A.; ALMEIDA, Edson Pacheco. Evasão nos cursos de graduação da Universidade Federal de Mato Grosso, campus universitário de Cuiabá: um processo de exclusão. In: Trabalho apresentado na $\mathbf{2 4}^{\text {a }}$ Reunião anual da ANPPED. Caxambu: out. 2001.

WING, NG H.; SILVA JÚNIOR, L. Determinantes Socioeconômicos na Probabilidade de Aprovação no Exame Vestibular: Uma análise entre os Campi da Universidade Federal de Pernambuco. Planejamento e Políticas Públicas - PPP, n. 37, jul./dez. 2011. 
ANEXOS 


\section{Regressão Logística - $\mathbf{1}^{\circ}$ Modelo (Reintegrados -R)}

\begin{tabular}{|c|c|c|c|c|c|c|c|c|c|}
\hline \multicolumn{10}{|c|}{ Variables in the Equation } \\
\hline & & \multirow[b]{2}{*}{ B } & \multirow[b]{2}{*}{ S.E. } & \multirow[b]{2}{*}{ Wald } & \multirow[b]{2}{*}{ df } & \multirow[b]{2}{*}{ Sig. } & \multirow[b]{2}{*}{$\operatorname{Exp}(B)$} & \multicolumn{2}{|c|}{ 95\% C.I.for EXP(B) } \\
\hline & & & & & & & & Lower & Upper \\
\hline \multirow[t]{24}{*}{ Step $1^{a}$} & Sexo &,- 343 & ,049 & 48,950 & 1 & ,000 & ,709 & ,644 & ,781 \\
\hline & $\begin{array}{l}\text { EscolaPriv } \\
\text { ada }\end{array}$ &, 560 &, 063 & 79,900 & 1 & ,000 & 1,750 & 1,548 & 1,979 \\
\hline & Norte(1) & ,200 & , 105 & 3,659 & 1 & ,056 & 1,222 & ,995 & 1,500 \\
\hline & Sul(1) & ,402 & 0,14205881 & 8,006736 & 1 & 0,00466 & 1,49476964 & 1,131 & 1,975 \\
\hline & $\mathrm{FAV}(1)$ & ,455 & ,186 & 5,972 & 1 & 015 & 1,576 & 1,094 & 2,270 \\
\hline & FAU(1) &,- 275 & ,280 & ,963 & 1 & ,326 & ,760 & ,439 & 1,316 \\
\hline & $\mathrm{FS}(1)$ &,- 561 & ,131 & 18,459 & 1 & ,000 &, 571 & ,442 & ,737 \\
\hline & $\mathrm{FAC}(1)$ &,- 589 & ,195 & 9,100 & 1 & ,003 &, 555 & ,378 & ,813 \\
\hline & $\mathrm{FD}(1)$ & 1,159 & ,229 & 25,643 & 1 & ,000 & 3,188 & 2,035 & 4,994 \\
\hline & $\mathrm{FM}(1)$ & $-2,106$ & ,252 & 69,875 & 1 & ,000 & ,122 & ,074 & ,199 \\
\hline & $\mathrm{FT}(1)$ & ,996 & ,103 & 94,342 & 1 & ,000 & 2,708 & 2,215 & 3,311 \\
\hline & $\mathrm{IB}(1)$ &,- 536 & ,143 & 13,987 & 1 & ,000 &, 585 & ,442 & ,775 \\
\hline & $\mathrm{IE}(1)$ & ,209 & ,088 & 5,711 & 1 & ,017 & 1,233 & 1,038 & 1,463 \\
\hline & IPOL(1) &,- 608 & ,143 & 18,094 & 1 & ,000 &, 545 & ,412 & ,721 \\
\hline & $\mathrm{IG}(1)$ & ,430 & ,215 & 3,989 & 1 & ,046 & 1,538 & 1,008 & 2,346 \\
\hline & $\mathrm{IP}(1)$ & ,716 & ,250 & 8,220 & 1 & ,004 & 2,047 & 1,254 & 3,341 \\
\hline & $\operatorname{FCE}(1)$ & 1,574 & ,442 & 12,673 & 1 & ,000 & 4,828 & 2,029 & 11,489 \\
\hline & FUP(1) &, 590 & ,227 & 6,750 & 1 & ,009 & 1,803 & 1,156 & 2,813 \\
\hline & $\begin{array}{l}\text { Idadelngre } \\
\text { sso }\end{array}$ &,- 007 & ,004 & 3,885 & 1 & ,049 & ,993 & ,986 & 1,000 \\
\hline & $\begin{array}{l}\text { TempoPer } \\
\text { manência }\end{array}$ & ,863 & ,013 & 4305,981 & 1 & ,000 & 2,371 & 2,311 & 2,433 \\
\hline & $\begin{array}{l}\text { Estrangeir } \\
o(1)\end{array}$ & ,822 & ,232 & 12,504 & 1 & ,000 & 2,275 & 1,442 & 3,587 \\
\hline & $\begin{array}{l}\text { Vestibular( } \\
\text { 1) }\end{array}$ & ,222 & ,057 & 15,355 & 1 & ,000 & 1,248 & 1,117 & 1,395 \\
\hline & Cotista(1) &,- 442 & ,091 & 23,722 & 1 & ,000 & ,643 &, 538 & ,768 \\
\hline & Constant & $-6,657$ & ,958 & 48,321 & 1 & ,000 & ,001 & & \\
\hline
\end{tabular}

\begin{tabular}{|l|c|r|c|}
\hline \multicolumn{4}{|c|}{ Model Summary } \\
\hline Step & $\begin{array}{c}-2 \text { Log } \\
\text { likelihood }\end{array}$ & $\begin{array}{c}\text { Cox \& Snell } \\
\text { R Square }\end{array}$ & $\begin{array}{c}\text { Nagelkerke R } \\
\text { Square }\end{array}$ \\
\hline 1 & $11921,458^{\mathrm{a}}$ &, 402 &, 584 \\
\hline
\end{tabular}

\begin{tabular}{|l|r|c|r|}
\hline \multicolumn{4}{|c|}{ Hosmer and Lemeshow Test } \\
\hline Step & Chi-square & df & \multicolumn{1}{|c|}{ Sig. } \\
\hline 1 & 332,697 & & 8 \\
\hline
\end{tabular}

Classification Table ${ }^{a, b}$

\begin{tabular}{|c|c|c|c|c|c|}
\hline & \multirow[b]{3}{*}{ Observed } & & \multicolumn{3}{|c|}{ Predicted } \\
\hline & & & \multicolumn{2}{|c|}{ Reintegrado } & \multirow{2}{*}{$\begin{array}{l}\text { Percentag } \\
\text { e Correct }\end{array}$} \\
\hline & & & 0 & 1 & \\
\hline \multirow[t]{3}{*}{ Step 0} & \multirow{2}{*}{$\begin{array}{l}\text { Reintegra } \\
\text { do }\end{array}$} & 0 & 11122 & 0 & 100,0 \\
\hline & & 1 & 4530 & 0 & ,0 \\
\hline & \multicolumn{2}{|c|}{ Overall Percentage } & & & 71,1 \\
\hline
\end{tabular}

Regressão Logística - $2^{\circ}$ Modelo (Reintegrados Formados -RF) 


\begin{tabular}{|c|c|c|c|c|c|c|c|c|c|}
\hline \multicolumn{10}{|c|}{ Variables in the Equation } \\
\hline & & \multirow[b]{2}{*}{ B } & \multirow[b]{2}{*}{ S.E. } & \multirow[b]{2}{*}{ Wald } & \multirow[b]{2}{*}{$\mathrm{df}$} & \multirow[b]{2}{*}{ Sig. } & \multirow[b]{2}{*}{$\operatorname{Exp}(B)$} & \multicolumn{2}{|c|}{ 95\% C.I.for EXP(B) } \\
\hline & & & & & & & & Lower & Upper \\
\hline \multirow[t]{16}{*}{ Step $1^{a}$} & Sexo & $\begin{array}{l}-395 \\
\end{array}$ & ,129 & 9,430 & 1 & ,002 & 674 & ,523 & ,867 \\
\hline & EscolaPriv & 1,013 & ,215 & 22,251 & 1 &, 000 & 2,755 & 1,808 & 4,198 \\
\hline & COsemDF & ,453 & ,260 & 3,043 & 1 & 081 & 1,574 & ,946 & 2,619 \\
\hline & Nordeste & ,361 & 0,21590164 & 2,791292 & 1 & 0,094778 & 1,434348 & ,939 & 2,190 \\
\hline & FS & 1,586 & ,718 & 4,882 & 1 & ,027 & 4,882 & 1,196 & 19,926 \\
\hline & FD &,- 933 & ,402 & 5,406 & 1 & ,020 & ,393 & 179 & ,864 \\
\hline & FM & 1,523 & ,718 & 4,503 & 1 & ,034 & 4,584 & 1,123 & 18,707 \\
\hline & FT &,- 806 & ,203 & 15,691 & 1 &, 000 & ,447 & 300 & ,666 \\
\hline & IB &,- 594 & ,270 & 4,826 & 1 & 028 &, 552 & ,325 & ,938 \\
\hline & IE &,- 887 & ,178 & 24,826 & 1 &, 000 & ,412 & ,291 & ,584 \\
\hline & IF &,- 630 & ,283 & 4,966 & 1 & ,026 & ,533 & ,306 & ,927 \\
\hline & IL & ,472 & ,228 & 4,298 & 1 & ,038 & 1,603 & 1,026 & 2,505 \\
\hline & $\begin{array}{l}\text { Idadelngre } \\
\text { sso }\end{array}$ &,- 146 &, 060 & 5,907 & 1 &, 015 & ,864 & ,769 & ,972 \\
\hline & Id2 & ,002 &, 001 & 4,674 & 1 & ,031 & 1,002 & 1,000 & 1,004 \\
\hline & OutrasFI & 1,156 & ,725 & 2,539 & 1 & , 111 & 3,177 & ,766 & 13,169 \\
\hline & Constant & 4,867 & ,814 & 35,771 & 1 &, 000 & 129,875 & & \\
\hline
\end{tabular}

\begin{tabular}{|l|r|r|r|}
\hline \multicolumn{4}{|c|}{ Model Summary } \\
\hline Step & $\begin{array}{c}-2 \text { Log } \\
\text { likelihood }\end{array}$ & $\begin{array}{c}\text { Cox \& Snell } \\
\text { R Square }\end{array}$ & $\begin{array}{c}\text { Nagelkerke } \\
\text { R Square }\end{array}$ \\
\hline 1 & $2287,399^{\mathrm{a}}$ &, 029 &, 075 \\
\hline
\end{tabular}

\begin{tabular}{|l|r|c|r|}
\hline \multicolumn{4}{|c|}{ Hosmer and Lemeshow Test } \\
\hline Step & Chi-square & df & \multicolumn{1}{c|}{ Sig. } \\
\hline 1 & 9,526 & & 8 \\
\hline
\end{tabular}

\begin{tabular}{|c|c|c|c|c|c|}
\hline \multicolumn{6}{|c|}{ Classification Table ${ }^{a}$} \\
\hline & \multirow{3}{*}{\multicolumn{2}{|c|}{ Observed }} & \multicolumn{3}{|c|}{ Predicted } \\
\hline & & & \multicolumn{2}{|c|}{ RF } & \multirow[b]{2}{*}{ fentage Co } \\
\hline & & & 0 & 1 & \\
\hline \multirow[t]{3}{*}{ Step 1} & \multirow[t]{2}{*}{$\mathrm{RF}$} & 0 & 0 & 332 & 0 \\
\hline & & 1 & 0 & 4606 & 100,0 \\
\hline & \multicolumn{2}{|c|}{ Overall Percentage } & & & 93,3 \\
\hline
\end{tabular}


Dispõe sobre a orientação acadêmica de estudante de graduação e condições para desligamento.

\begin{abstract}
O PRESIDENTE DA FUNDAÇÃO, REITOR DA UNIVERSIDADE DE BRASÍLIA E PRESIDENTE DO CONSELHO DE ENSINO, PESQUISA E EXTENSÃO, no uso de suas atribuições estatutárias, considerando o disposto no parágrafo único do art. 125 do Regimento Geral da UnB e ouvido o referido Órgão Colegiado, em sua $382^{\text {a }}$ Reunião, realizada em 23/4/2004,
\end{abstract}

R E S O L E:

\title{
Capítulo I - Da Orientação Acadêmica
}

Art. 1ํㅗㄹ fins da presente Resolução, entende-se por orientação acadêmica o exercício do diálogo continuado que perpassa a vida acadêmica de estudantes e professores e apresenta qualidades tais que permitam 0 aproveitamento recíproco de suas experiências e a compreensão das relações estudante-professor.

Art. $2^{\circ}$ A orientação acadêmica é assegurada para o estudante de graduação nas seguintes condições:

I - até a integralização de pelo menos cinqüenta por cento do total de créditos do seu curso.

II - estar em situação de risco de desligamento.

Art. $3^{\circ}$ A orientação acadêmica ocorrerá conforme as seguintes modalidades:

I - orientação individualizada: que se realiza mediante relação direta entre um professor orientador e o estudante.

II - orientação tutorial: aquela que inclui a modalidade anterior e que prevê também a relação entre um professor orientador e um grupo determinado de estudantes.

III - orientação dirigida: voltada para atender casos específicos de estudantes que procuram a DAIA/DEG, que sejam encaminhados a esta por orientadores ou coordenadores de cursos ou, ainda, que sejam convocados por esta com base em indícios de risco de desligamento. 
IV - outras modalidades de orientação acadêmica em consonância com os objetivos precípuos desta Resolução, a critério do Colegiado do Curso e com a aprovação da Diretoria de Acompanhamento e Integração Acadêmica DAIA/DEG.

Art. $4^{\circ}$ São professores orientadores todos aqueles do quadro permanente da Universidade de Brasília com experiência mínima de 3 (três) anos em docência em IES, sendo pelo menos 1 (um) ano na UnB.

Art. $5^{\circ}$ O exercício das atividades de orientação acadêmica será precedido de um processo de preparação e instrumentação do professor orientador sob a responsabilidade conjunta da Coordenação do Curso, da DAIA e da DAA.

Art. 6ํㅜ Caberá aos Colegiados dos Cursos de Graduação:

I - indicar o(s) orientador (es) para os estudantes ingressos em seus cursos e para os estudantes em situação de risco de desligamento.

II - aprovar as ações vinculadas à orientação acadêmica, consubstanciando o plano global de orientação;

III - subsidiar e apoiar a Coordenação de Curso na elaboração do plano global de orientação acadêmica;

IV - proceder à indicação e ou substituição dos professores que realizarão as atividades de orientação acadêmica no período letivo seguinte.

Parágrafo único. O plano global de orientação do curso é aquele que define a modalidade de orientação a ser implementada no curso, bem como ações previstas e a necessidade ou não de relatórios, individuais ou consolidados, conforme a decisão dos colegiados.

Art. $7^{0}$ São atribuições do professor orientador:

I - instruir os seus orientados sobre a estrutura e funcionamento acadêmicos da Universidade de Brasília;

II - organizar com cada orientando um projeto acadêmico que articule as funções de ensino, pesquisa e extensão;

III - identificar dificuldades e impedimentos quanto ao cumprimento das atividades acadêmicas de seus orientados, procedendo aos encaminhamentos necessários à superação dos mesmos;

IV - proceder, em consonância com o calendário universitário, à orientação do estudante na escolha das disciplinas que irá cursar; 
V - colaborar na composição da lista de oferta de disciplinas, informando ao Coordenador de Curso sobre interesses e necessidades de seus orientados;

VI - analisar as solicitações de alteração nos compromissos acadêmicos dos seus orientados, a exemplo de trancamentos, exercícios domiciliares, estágios, monitorias, entre outros, opinando a respeito;

VII - estabelecer e divulgar horários disponíveis para atendimento aos orientados;

VIII - comunicar ao Coordenador de Curso aspectos da orientação que excedam o âmbito de sua competência;

IX - colaborar com o Serviço de Orientação ao Universitário/SOU e com demais serviços de apoio ao estudante.

Capítulo II - Da Orientação de Estudantes em Risco de Desligamento

Art. $8^{\circ} \mathrm{O}$ estudante de Graduação será desligado da Universidade nas seguintes situações:

I - Abandono de curso;

II - Voluntariamente;

III - Jubilamento;

IV - Rendimento acadêmico.

Art. 9ำ O Desligamento por ABANDONO DE CURSO é a forma de exclusão automática do cadastro discente da UnB do estudante que, durante 2 (dois) períodos letivos consecutivos, não tenha efetivado matrícula em disciplinas, ou que, embora matriculado, não tenha cursado disciplina.

Art. 10. O Desligamento VOLUNTÁRIO é a forma de exclusão do cadastro discente da UnB do estudante que, por iniciativa própria, tenha desistido do vínculo com seu curso.

Parágrafo único. O estudante aprovado em novo concurso vestibular, que optar pelo novo curso, será desligado do curso anterior na presente modalidade.

Art. 11. O Desligamento por JUBILAMENTO é a forma de exclusão do cadastro discente da UnB do estudante que tenha esgotado o tempo máximo de permanência estabelecido para a conclusão do curso.

Art. 12. O Desligamento por RENDIMENTO ACADÊMICO é a forma de exclusão do cadastro discente da UnB do estudante que não tenha cursado com aproveitamento 4 (quatro) disciplinas do seu curso em 2 (dois) períodos 
letivos regulares consecutivos, que tenha sido reprovado 3 (três) vezes na mesma disciplina obrigatória de seu curso, ou que não tenha cumprido condição imposta em fase probatória.

Art. 13. Cabe à Comissão de Acompanhamento e Orientação/CAO do Decanato de Ensino de Graduação identificar, notificar e encaminhar para 0 estudante a orientação de desligamento.

Parágrafo único. A CAO será designada pelo Decano de Ensino de Graduação e terá representantes da Diretoria de Administração Acadêmica - DAA, da Diretoria de Acompanhamento e Integração Acadêmica - DAIA, do corpo docente e do corpo discente.

Art. 14. O estudante em situação de risco de desligamento poderá ser submetido a FASE PROBATÓRIA na qual deverá cumprir as condições estabelecidas para o caso.

$\S 1^{0}$ Caberá à CAO coordenar a análise e o encaminhamento dos casos de estudantes em situação de risco de desligamento, com a participação dos orientadores.

$\S 2^{\circ}$ Suspendem-se, enquanto durar a fase probatória do estudante, a aplicação dos critérios gerais de desligamento.

Art. 15. Os casos omissos serão resolvidos pela Câmara de Ensino de Graduação.

Art. 16. A presente Resolução entrará em vigor nesta data revogadas as disposições em contrário.

Brasília, 10 de maio de 2004.

Lauro Morhy

Reitor 


\title{
INSTRUÇÃO NORMATIVA DA CÂMARA DE ENSINO DE GRADUAÇÃO
}

N. ${ }^{\circ} 001 / 2012$

\author{
Estabelece procedimentos para \\ tratar de processos de discente \\ em risco de desligamento \\ reintegração e orientação \\ acadêmica.
}

A CÂMARA DE ENSINO DE GRADUAÇÃO, no uso de suas atribuições, de acordo com a deliberação da CEG, em sua $1255^{\mathrm{a}}$ e $1256^{\mathrm{a}}$ reuniões, realizadas em 14/08/2012 e 28/08/2012, e considerando o disposto no art.125 do Regimento Geral da UnB e nos os artigos 13 e 14 da Resolução do Conselho de Ensino, Pesquisa e Extensão N041/2004, e

CONSIDERANDO que é desligado(a) da UnB o(a) discente regularmente matriculado(a) em Curso de Graduação, reprovado(a) três vezes em uma mesma disciplina obrigatória, por não ter cumprido condição imposta em fase probatória ou por ter terminado o período de máxima permanência permitido pelo Projeto Político-Pedagógico do Curso,

CONSIDERANDO que há grande número de processos de reintegração encaminhados aos Coordenadores de Curso de Graduação para análise e elaboração de Plano de Estudos,

CONSIDERANDO que cabe aos Colegiados dos Cursos de Graduação indicar orientadores para os(as) discentes, aprovar as ações vinculadas à orientação acadêmica, bem como subsidiar e apoiar a Coordenação de Curso na elaboração do Plano Global de Orientação Acadêmica,

CONSIDERANDO que são diversos os motivos que levam ao desligamento, à evasão e à retenção decorrentes de dificuldades de comunicação entre os diferentes segmentos da comunidade universitária,

CONSIDERANDO que é dever da instituição zelar pela permanência e bom rendimento dos discentes regularmente matriculados,

I N S T R U I: 


\section{Capitulo I}

\section{Da capacitação, orientação e difusão da informação sobre a vida acadêmica}

Art. $\mathbf{1}^{\circ}$ - Cabe aos Colegiados dos Cursos de Graduação a responsabilidade pela informação de docentes, servidores e discentes sobre as normas da Universidade, recorrendo à SAA, ao DGP e ao DEG para capacitação e orientação de servidores e docentes.

Art. $\mathbf{2}^{\mathbf{0}}$ - Cabe aos Colegiados de Curso criar estratégias próprias para informação e orientação de discentes, podendo recorrer à SAA ou a DAIA/SOU para apoio às estratégias encontradas.

Art. $3^{\circ}$ - Cabe à SAA e ao DEG a capacitação de servidores e docentes sobre as normas e procedimentos referentes às questões acadêmicas dos Cursos de Graduação, particularmente, IRA (Índice de Rendimento Acadêmico), TGM (trancamento geral de matrícula), mudança de curso, duplo curso, duplahabilitação, fase probatória (risco de desligamento), desligamento e reintegração.

Art. $4^{\mathbf{0}}$ - Cabe à DAIA, com apoio da Comissão de Acompanhamento e Orientação (CAO):

I - propor ações para orientação de docentes, coordenadores e discentes que promovam a permanência de discentes nos Cursos de Graduação;

II - avaliar estatísticas de evasão e rendimento de discentes de graduação;

III - indicar ações de acompanhamento das diversas situações que levem ao afastamento de discentes;

IV - estabelecer ações de integração e recuperação acadêmicas de discentes.

Art. $5^{\circ}$ - A Secretaria de Administração Acadêmica - SAA - encaminhará às Coordenações de Graduação relação de discentes desligados por rendimento acadêmico ou que devam cumprir condição para permanecer no Curso.

Art. $\mathbf{6}^{\circ}$ - Cada curso deverá analisar a relação de discentes recebida da SAA e enviar ao DEG relatório semestral, aprovado pelo Colegiado de Curso, contendo o número de discentes em condição e discentes desligados, bem como averiguar 
os motivos para tal, o número de pedidos de reintegração analisados pelo Colegiado de Curso, o número de pedidos deferidos e as estratégias propostas para lidar com a situação diagnosticada.

\section{Capitulo II}

\section{Do(a) discente em risco de desligamento}

Art. $7^{\circ}-\mathrm{O}$ (a) discente encontrar-se-á em risco de desligamento, quando:

I - tiver duas reprovaçōes na mesma disciplina obrigatória;

II - não tiver sido aprovado, em pelo menos, 4 (quatro) disciplinas do seu curso, em dois períodos letivos regulares consecutivos:

III - chegar ao último período letivo permitido no projeto pedagógico do seu curso sem possibilidades de concluí-lo.

Art. $\mathbf{8}^{\mathbf{0}}$ - O(a) discente em risco de desligamento terá de ser acompanhado(a) por orientador(a) acadêmico(a) e deverá cumprir uma das seguintes condições, correspondendo, respectivamente, às situações descritas no art. $7^{\circ}$ :

I - ser aprovado(a) nas disciplinas obrigatórias anteriormente cursadas com duas reprovações;

II - ser aprovado(a), em pelo menos, no número mínimo de créditos estabelecido pelo curso, em cada um dos dois períodos letivos subsequentes;

III - cumprir plano de estudo aprovado pela CAO:

a - O plano de estudo é o planejamento das disciplinas a serem cursadas com probabilidade de êxito pelo(a) discente.

Parágrafo Único. Será considerado desligado o aluno que não cumprir as condiçōes descritas nos incisos I, II ou III do Art. $8^{\circ}$.

Art. $9^{\circ}-\mathrm{O}$ (a) discente em risco de desligamento terá de ser acompanhado(a) por orientador(a) acadêmico(a), que:

I - ficará responsável por elaborar, com a(o) discente, um Plano de

Estudos para um ou dois semestres, no caso do art. $7^{\circ}$, inciso III, 
considerando a situação acadêmica e justificativas apresentadas pelo(a) discente;

II - acompanhará, junto ao(à) discente, o cumprimento das exigências de sua condição.

\section{Capitulo III}

Da reintegração

Art. $10^{\circ}-\mathrm{O}$ prazo máximo para solicitação de reintegração é de dois (2) anos, contados a partir da data de desligamento.

Art. $\mathbf{1 1}^{\circ}$ - A solicitação de reintegração será feita nos Postos de Atendimento da SAA, que a encaminhará à respectiva Coordenação do Curso.

Art. $\mathbf{1 2}^{\circ}$ - Os Colegiados de Cursos de Graduação encaminharão à CAO parecer técnico sobre o pedido de reintegração.

Art. $1^{\circ}$ - Caso a reintegração seja recomendada, será indicado(a), pelo Colegiado, um(a) orientador(a), que ficará responsável por elaborar, junto com o(a) discente, um Plano de Estudos ou definição de outra condição, para um ou dois semestres, considerando a situação acadêmica e a justificativa apresentada pelo(a) discente.

Art. $1^{\circ}$ - À CAO caberá a análise do processo e poderá recomendar à CEG a reintegração de discentes que atendam às condições abaixo listadas:

I - Quando for apresentada, pelo ex-aluno, justificativa para o desligamento e demonstrado que tal situação foi sanada, permitindo a conclusão do Curso.

$\S 1 .^{\circ}$ - Justificativas envolvendo questões de saúde devem ser comprovadas com atestado médico.

$\S 2 .^{\circ}$ - Justificativas envolvendo outros problemas passíveis de apresentação de documentos formais também devem ser acompanhadas de comprovação. 
$\S 3 .^{\circ}$ - Outros documentos comprobatórios poderão ser solicitados por quaisquer comissões ou instâncias envolvidas na tramitação do processo.

II - quando o número de créditos necessários para finalizar o Curso puder ser cursado dentro do período máximo de permanência definido para o Curso.

III - quando o(a) discente estiver afastado(a) da Universidade por um período não superior a 4 semestres letivos.

Art. $1^{\circ}$ - Casos omissos nesta instrução serão resolvidos pela Câmara de Ensino de Graduação (CEG).

Art. $16^{\circ}$ - Esta Instrução Normativa entra em vigor nesta data e torna sem efeito a Instrução Normativa 001/2009.

Brasília, 04 de setembro de 2012.

Prof. José Américo Soares Garcia

Presidente da Câmara de Ensino de Graduação 


\section{INSTRUÇÃO NORMATIVA DA CÂMARA DE ENSINO DE GRADUAÇÃO N. ${ }^{\circ} 001 / 2014$}

Estabelece procedimentos para
tratar de processos de
reintegração de discente
desligado.

A CÂMARA DE ENSINO DE GRADUAÇÃO, no uso de suas atribuições, de acordo com a deliberação da CEG, em sua $1301^{\text {a }}$ reunião, realizada em 11/11/2014, e com o disposto no artigo $7^{\circ}$ da Resolução do Conselho de Ensino, Pesquisa e Extensão № 041/2004,

CONSIDERANDO que é desligado(a) da UnB o(a) discente regularmente matriculado(a) em Curso de Graduação, reprovado(a) três vezes em uma mesma disciplina obrigatória, por não ter cumprido condição, por ter terminado o período de máxima permanência permitido pelo Projeto Pedagógico do Curso ou por abandono,

CONSIDERANDO o número de processos de reintegração encaminhados aos Coordenadores de Curso de Graduação para análise e elaboração de Plano de Acompanhamento Acadêmico,

CONSIDERANDO que cabe aos Colegiados dos Cursos de Graduação indicar orientadores para os(as) discentes, aprovar as açōes vinculadas à orientação acadêmica, bem como subsidiar e apoiar a Coordenação de Curso na elaboração do Plano de Orientação Acadêmica,

IN STRU I:

\section{Capitulo I}

Da reintegração

Art. $1^{\circ}$ - O prazo máximo para solicitação de reintegração é de um ano, contado a partir da data de desligamento. 
Art. $2^{\mathbf{0}}$ - A solicitação de reintegração será feita nos Postos de Atendimento da SAA, que a encaminhará à respectiva Coordenação do Curso, obedecendo critérios e cronograma constantes em edital do DEG.

Parágrafo único. Serão permitidas, no máximo, duas reintegrações na Universidade de Brasilia.

Art. $3^{\circ}$ - Ao Colegiado de Curso de Graduação caberá a análise do processo e deliberar sobre a reintegração de discentes que atendam às condições abaixo listadas:

I - Apresentação, pelo ex-aluno, de justificativa do desligamento, demonstrando que tal situação foi sanada.

$\S 1 .^{\circ}$ - Justificativas envolvendo questōes de saúde devem ser comprovadas com atestado ou relatório médico.

$\S 2 .^{\circ}$ - Justificativas envolvendo outros problemas passíveis de apresentação de documentos formais devem ser acompanhadas de comprovação.

$\S 3 .^{\circ}-$ Outros documentos comprobatórios poderão ser solicitados pelo Colegiado de Curso de Graduação.

II - O número de créditos necessários para o(a) ex-aluno(a) finalizar o Curso puder ser cursado dentro do período máximo de permanência no Curso.

III - O(a) ex-aluno(a) estiver afastado(a) da Universidade por um período igual ou inferior a um ano.

Art. $4^{\circ}$ - Caso a reintegração seja aprovada, o Colegiado de Curso de Graduação indicará um(a) professor(a) orientador(a) responsável por elaborar, junto com o discente, um plano de acompanhamento acadêmico, considerando a situação acadêmica e a justificativa apresentada pelo discente, conforme atribuições 
estabelecidas no artigo $7^{\circ}$ da Resolução do Conselho de Ensino, Pesquisa e Extensão No 041/2004.

Parágrafo único - É facultado ao discente reintegrado solicitar substituição do(a) professor(a) orientador(a).

Art. $5^{\mathbf{0}}$ - O discente reintegrado deverá ser aprovado em, no mínimo, quatro disciplinas obrigatórias e/ou optativas do Curso em dois semestres consecutivos.

Parágrafo único - O discente reintegrado também será desligado se obtiver a terceira reprovação em disciplina obrigatória.

Art. $\mathbf{6}^{\circ}$ - O Colegiado de Curso de Graduação deverá encaminhar os processos analisados para a SAA para devidas providências, respeitando-se o cronograma estabelecido em edital.

Art. $7^{\circ}$ - Recursos da decisão do Colegiado de Curso de Graduação deverão ser encaminhados à CEG, respeitando-se o cronograma estabelecido em edital.

Art. $\mathbf{8}^{\mathbf{0}}$ - Casos omissos serão resolvidos pela Câmara de Ensino de Graduação (CEG).

Art. $9^{\circ}$ - Esta Instrução Normativa entra em vigor em 01 de janeiro de 2015, e torna sem efeito o Capítulo III da Instrução Normativa da CEG Nº 001/2012.

Brasília, 02 de dezembro de 2014.

Prof. Mauro Luiz Rabelo

Presidente da Câmara de Ensino de Graduação 